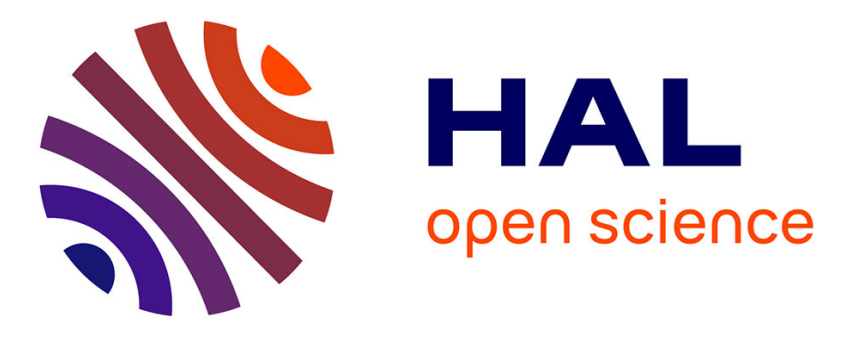

\title{
Climate change impacts on multi-objective reservoir management: case study on the Seine River basin, France
}

D. Dorchies, Guillaume Thirel, M. Jay-Allemand, M. Chauveau, F. Dehay, P.Y. Bourgin, Charles Perrin, C. Jost, J.L. Rizzoli, S. Demerliac, et al.

\section{To cite this version:}

D. Dorchies, Guillaume Thirel, M. Jay-Allemand, M. Chauveau, F. Dehay, et al.. Climate change impacts on multi-objective reservoir management: case study on the Seine River basin, France. International Journal of River Basin Management, 2014, 12 (3), pp.265-283. 10.1080/15715124.2013.865636 . hal-01122348

\section{HAL Id: hal-01122348 \\ https://hal.science/hal-01122348}

Submitted on 3 Mar 2015

HAL is a multi-disciplinary open access archive for the deposit and dissemination of scientific research documents, whether they are published or not. The documents may come from teaching and research institutions in France or abroad, or from public or private research centers.
L'archive ouverte pluridisciplinaire HAL, est destinée au dépôt et à la diffusion de documents scientifiques de niveau recherche, publiés ou non, émanant des établissements d'enseignement et de recherche français ou étrangers, des laboratoires publics ou privés. 


\section{Climate change impacts on multi-objective reservoir management: case study on the Seine River basin, France}

David Dorchies $^{(1)}$, Guillaume Thirel ${ }^{(2)}$, Maxime Jay-Allemand ${ }^{(1)}$, Mathilde Chauveau ${ }^{(2,3)}$, Florine Dehay $^{(1)}$, Pierre-Yves Bourgin ${ }^{(2,4)}$, Charles Perrin ${ }^{(2)}$, Claudine Jost ${ }^{(5)}$, Jean-Louis Rizzoli ${ }^{(5)}$, Stéphane Demerliac $^{(5)}$, Régis Thépot ${ }^{(5)}$

(1) Irstea, UMR G-Eau, 361 rue Jean-François Breton, BP 5095, 34196 Montpellier cedex 5

(2) Irstea, UR HBAN, 1, rue Pierre-Gilles de Gennes, CS 10030, 92761 Antony Cedex

(3) Now at: BRLi, 1105, av. Pierre Mendès France, BP 94001, 30001 Nîmes Cedex 5

(4) Now at: Tractebel Engineering S.A. - Coyne et Bellier, Le Delage, 5 rue du 19 mars 1962, 92622 Gennevilliers Cedex

${ }^{(5)}$ Seine Grands Lacs, 8, rue Villiot, 75012 Paris 


\begin{abstract}
Adaptation strategies will be needed to cope with the hydrological consequences of projected climate change. In this perspective, the management of many artificial reservoirs will have to be adapted to continue to fulfil downstream objectives (e.g. flow regulation). This study evaluates

5 the sustainability of the management rules of the artificial reservoirs on the Seine River basin, France, under climate change scenarios. The Seine River basin at Paris $\left(43,800 \mathrm{~km}^{2}\right)$ has major socio-economic stakes for France, and the consequences of droughts and floods may be dramatic. In this context, four large multi-purpose reservoirs were built on the basin during the $\mathrm{XX}^{\text {th }}$ century for low-flow augmentation and flood alleviation.

10 A hydrological modelling chain was designed to explicitly account for reservoir management rules. It was calibrated in current conditions and then fed by the outputs of seven climate models in present and future conditions, forced by the A1B IPCC scenario, downscaled using a weather-type method and statistically bias-corrected.

The results show that the hydrological model performs quite well in current conditions. The

15 simulations made in present and future conditions indicate a decrease in water availability and summer low flows, but no significant trends in high flows. Simulations also indicate that there is room for progress in the current multi-purpose management of reservoirs and that it would be useful to define proper adaptation strategies.
\end{abstract}

\title{
Keywords
}


Author-produced version of the article published in International Journal of River Basin Management JRBM, 2014, N¹2(3), p. 265-283.

\section{Introduction}

\section{I.1. Artificial reservoirs under climate change}

Artificial reservoirs are essential tools for water resources management. They are used for various objectives, ranging from water supply, irrigation, protection against floods to recreation. Their management rules are all the more complex as several objectives are concerned and downstream pressures are strong (e.g. for preservation of aquatic life). Designed under current climate conditions, these rules may, however, not be suitable if climate conditions were to change or the socio-economic environment were to substantially evolve.

Thus the short-, medium- or long-term management practices may have to be modified to adapt to the climate and socio-economic scenarios projected by the Intergovernmental Panel on Climate Change (IPCC, 2007) for the $21^{\text {st }}$ century. This has already been recognized as a major issue in water resources management, and several authors have proposed adaptation strategies of dam management in various contexts (see e.g. Slavik and Uhl, 2009; Eum and Simonovic, 2010; Georgakakos et al., 2012; Oni et al., 2012). The first step before proposing adaptation, however, is to make a detailed diagnosis of the sustainability of current management practices.

\section{I.2. The case of the Seine river basin}

In France, all large river basins are impacted by artificial reservoirs. Many large dams were built for hydropower, but also for flow regulation. This is the case of the Seine river basin (total size, $78,650 \mathrm{~km}^{2}$ ) located in northern France, where four large dams with a total storage capacity of $805 \mathrm{hm}^{3}$ ) are managed for low-flow augmentation and flood alleviation by the Seine Grands Lacs institution (www.seinegrandslacs.fr). They were built after dramatic floods (in 1910 and 1924) and low-flow (in the 1920s) events, which had major consequences mainly on the Paris area (Ambroise-Rendu, 1997). Other cities along the Seine river are also subject to water-related risks upstream (e.g. the city of Troyes) or downstream (e.g. the city of Rouen) of Paris. The basin has a major economic role in France because it provides drinking water to almost 20 million persons, includes a large number of factories, and is a major agricultural and touristic region. 
Author-produced version of the article published in International Journal of River Basin Management JRBM, 2014, N¹2(3), p. 265-283. The original publication is available at http://www.tandfonline.com

Doi: 10.1080/15715124.2013.865636

For all these reasons, better knowledge and anticipation of the impacts of climate change on the Seine River basin is becoming critical. Over the last decade, several studies have assessed the impacts of climate change on the hydrology of the Seine River basin. Ducharne et al. (2007) studied the impact of climate change on the hydrological and biochemical functioning of the Seine River basin within the GICC-Seine project. They concluded that water quality would not be dramatically altered. Boé et al. (2009) used several climate models and studied the evolution of discharge over the main French river basins around the year 2050. For the Seine River, they found a clear decrease of discharge during summer, whereas the change was more uncertain during winter. Ducharne et al. (2011) adopted a multi-model approach to describe the evolution of water resources and extremes over the Seine River and the Somme River basins within the RExHySS project. Two greenhouse gas emission scenarios, 15 climate models, three downscaling methods and five hydrological models were used. All models agreed on an increase of the

60 frequency of severe drought, but their answer concerning the frequency of floods was uncertain. They also showed that increasing irrigation or decreasing recharge of aquifers could lead to a severe decrease of aquifer water levels. Recently, the Explore2070 project attempted to define adaptation strategies to cope with hydrological climate change over France. The results corroborated the conclusions of Ducharne et al. (2011) about the evolution of floods and droughts (Chauveau et al., 2013) and aquifer water levels for the Seine basin.

\section{I.3. Scope of the study}

These past studies did not specifically assess the impacts of climate change on dam management, as they considered rivers as unregulated. Therefore, the focus of the present study was to analyse the consequences of climate change on dam management on the Seine basin. It is a case study application within the Climaware project funded by the Integrated Water Resources Management Network (IWRM-Net). The more general objective of the project is to propose adaptation strategies in response to climate change, based on a European modelling approach using the WaterGAP model (Doll and Fiedler, 2008) and three regional case studies focusing on hydromorphology (on the Eder River in Germany), agricultural water use (in the Apulia region in Italy), and dam management, the latter being the focus of this paper.

In section 2, we present the Seine River basin, the current management rules of reservoirs and the data used. In section 3 , the hydrological models and testing methodology are presented. In 
Author-produced version of the article published in International Journal of River Basin Management JRBM, 2014, Nº12(3), p. 265-283. The original publication is available at http://www.tandfonline.com

Doi: 10.1080/15715124.2013.865636

section 4, model performance is first evaluated in current conditions, with and without considering the impact of reservoirs. Then the evolution of the efficiency of management rules under climate change scenarios is assessed. Last, discussion and conclusions are provided on this work.

\section{Basin and data}

\section{II.1. The Seine River basin}

\section{II.1.a. Hydrological regime and regulation infrastructures}

85 This study focuses on the Seine River basin upstream from Paris $\left(43,800 \mathrm{~km}^{2}\right)$. The basin is under temperate oceanic conditions. The mean annual rainfall is $700 \mathrm{~mm}$; the potential evapotranspiration is at its maximum during summer (more than $90 \mathrm{~mm}$ a month between May and August) and is low during winter (less than $30 \mathrm{~mm}$ a month between November and February). The hydrology of this catchment is characterized by a low-flow period between summer and late autumn (July to October) and floods usually occur during spring (January to April).

The main rivers on the catchment are regulated by four large artificial reservoirs managed by Seine Grands Lacs (SGL) on the Marne, Aube, Seine and Yonne Rivers (see Figure 1), totalling a water storage capacity of $805 \mathrm{hm}^{3}$. On the Yonne River, the dam is a run-of-the-river type, while the three others bypass the river with inlet and outlet connections. The four reservoirs were built between the 1950s and 1980s and all the infrastructures were designed according to the known historical flood events and low-flow periods on the catchment. The reservoirs control $17 \%$ of the basin area at Paris.

\section{II.1.b. Current reservoir management rules}

100 Each reservoir is currently managed independently, which means that the management rules only depend on locally available data: the amount of water stored in the reservoir and the flows observed in the river reaches upstream and downstream of the reservoir.

During the year, each reservoir is filled and emptied following its own objective volume curve defined from historical floods and low-flow statistics. This curve consists in filling the reservoir 
Author-produced version of the article published in International Journal of River Basin Management JRBM, 2014, Nº12(3), p. 265-283. The original publication is available at http://www.tandfonline.com

Doi: 10.1080/15715124.2013.865636

between November $1^{\text {st }}$ and June $30^{\text {th }}$ and emptying it between July $1^{\text {st }}$ and October $31^{\text {st }}$. The emptying period can be prolonged until December $31^{\text {st }}$ in case of low flows under an alert threshold downstream from the lakes during this period. Following this curve, the level in the reservoirs is low before the winter-spring season, which helps alleviate floods, and is high at the beginning of the low-flow season, to serve for low-flow augmentation. This simple management

110 is possible given that floods and low flows occur at very different periods within the year on the basin, which may not be the case in other climatic contexts.

During the filling period, water is withdrawn from the river to the reservoirs up to a limit of a minimum regulatory flow for aquatic life preservation. If the top of the objective filling curve is not reached on July $1^{\text {st }}$, the objective curve becomes a straight line between the current volume on July $1^{\text {st }}$ and the objective volume on October $31^{\text {st }}$. During the emptying period, the reservoirs release water up to a limit of a maximum flow to avoid creating unexpected high flows downstream from the reservoirs.

Flood conditions are estimated based on the flow observed in the river at the inlet connections. If this flow exceeds a maximum threshold, the excess over threshold is diverted to the reservoir.

120 As soon as the flow in the river at the outlet connection falls below the maximum threshold defined at the outlet, the excess storage is progressively released from the lake to return to the volume defined by the objective curve.

\section{II.2. Data used}

\section{II.2.a. Flow and climate data in current conditions}

125 Twenty-five gauging stations spread over the main stream and its tributaries (see Figure 1 and Table 1) were used. These stations are commonly used for management objectives. Daily observed flow time series were collected from the national HYDRO database (www.hydro.eaufrance.fr). Naturalized flow data were provided by Seine Grands Lacs (Hydratec, 2011). These data provide an estimate of natural flows without the influence of the four main reservoirs. Note however that these data do not account for all human influences on the basins (e.g. not all withdrawals were considered, nor navigation dams), so the term "naturalized" is understood here as free of the influence of the four main reservoirs. 
Author-produced version of the article published in International Journal of River Basin Management JRBM, 2014, Nº12(3), p. 265-283. The original publication is available at http://www.tandfonline.com

Doi: 10.1080/15715124.2013.865636

Observed meteorological data (precipitation and temperature) were obtained from the MétéoFrance SAFRAN re-analysis (Vidal et al., 2010). SAFRAN provides daily grid data at an $8 \times 8-\mathrm{km}$ resolution that were lumped over the catchments. The potential evapotranspiration was obtained using the Penman-Monteith formula (Penman, 1948).

\section{II.2.b. Scenario and climate models}

Here we adopted a classical approach to derive hydrological projections based on climate scenarios. The A1B green gases emission scenario built by the Intergovernmental Panel on 140 Climate Change (IPCC, 2007) was chosen. It is considered a medium scenario. Seven GCMs were used: CCCMA-CGCM, ECHAM5-MPI, GFDL-CM2.0, GFDL-CM2.1, MRI-CGCM2.3.2, GISS-MODELER and ARPV3. They provide daily precipitation, temperature and potential evapotranspiration scenarios for the 01/08/1961-31/07/1991 period chosen as a reference for current conditions (hereafter called present period and noted PST) and the 01/08/2046-31/07/2065 target period

145 for future conditions (hereafter called future period and noted FUT). Since the spatial resolution of GCMs is too coarse to be used over the study basin, we used data previously downscaled at an $8 \times 8-\mathrm{km}$ resolution using a weather-type statistical method (the DSCLIM algorithm, Boé et al., 2006; Boe et al., 2007).

\section{II.2.c. Bias correction of climate projections}

150 Downscaling methods are prone to uncertainty (Quintana Segui et al., 2010) and downscaled scenarios are not free of bias. The GCM outputs downscaled over the Seine basin showed quite significant biases compared to observations over the present period, mostly during the summer season: precipitation was overestimated from July to November and potential evapotranspiration was underestimated from May to July (see Figure 2). The temperature evolution was much closer to observations.

To cope with these biases, the commonly adopted approach is to hypothesize that the impact of input biases on hydrological simulation will remain the same between present and future conditions and therefore to consider only differences between future and present conditions to quantify changes. This approach had a major drawback in our case: since we wished to quantify

160 the evolution of the dam management reliability between present and future conditions, using biased scenarios would consequently strongly bias the estimation of management reliability, with results that would be difficult to interpret. 
Author-produced version of the article published in International Journal of River Basin Management JRBM, 2014, Nº12(3), p. 265-283. The original publication is available at http://www.tandfonline.com

Doi: 10.1080/15715124.2013.865636

Therefore we chose to correct the bias in the downscaled climate simulations. A wide range of methods exist for this. Only recently several studies have started to rigorously assess the quality of the methods by comparing them. For example, Gudmundsson et al. (2012) compared diverse statistical methods for bias-correcting precipitation from regional climate models (RCM). Teutschbein and Seibert (2012) compared methods to bias-correct RCM precipitation and temperature. They both agreed that the distribution mapping (also called quantile-quantile mapping or $Q Q$ mapping) method performs best. So we selected the $Q Q$ mapping method for 170 the study. This method aims to fit the distribution of climate variables to the distribution of observations over a given period (here PST) and applies this transformation to the future time (Panofsky and Brier, 1968). We applied the QQ mapping to precipitation, potential evapotranspiration and temperature variables on a monthly basis. Note that the $Q Q$ mapping method, by definition, will equal the monthly averages and variances of the bias-corrected and 175 observed climate variables.

We observed (results not detailed here for the sake of brevity) that bias-correcting precipitation alone reduced the discharge bias mainly from September to November over the PST period, while the joint bias correction of precipitation and potential evapotranspiration brought improvements over the whole year (and more specifically from May to November). Biascorrecting temperature had a limited impact on discharge because the hydrological models use temperature only for simulating snow-related processes, which are not highly significant on the basin. However, we chose to bias-correct temperature series also in order to keep the temperature values consistent with the bias-corrected potential evapotranspiration values.

\section{Models and methods}

\section{III.1.The lumped GR4J hydrological model}

The GR4J model is a daily four-parameter lumped rainfall-runoff model. A full description is available in Perrin et al. (2003). Its four parameters are (1) the capacity of the production store $(\mathrm{mm})$, which acts as a buffer on rainfall, (2) the water exchange coefficient $(\mathrm{mm})$, which enables water losses to or gains from the deep aquifers, (3) the capacity of the non-linear routing store $(\mathrm{mm})$, which has an smoothing effect on effective rainfall, and (4) the unit hydrograph time base 
Author-produced version of the article published in International Journal of River Basin Management JRBM, 2014, N¹2(3), p. 265-283. The original publication is available at http://www.tandfonline.com

Doi: 10.1080/15715124.2013.865636

(days), which accounts for the reaction time of the basin. Parameters are calibrated against discharge data at the outlet of the study catchment. GR4J also accounts for snow accumulation and melt (see Valéry, 2010), although snow has a limited influence on the hydrology of the Seine River basin. The model has already been applied to the Seine basin, with quite satisfactory results (see e.g. Moulin et al., 2005). In this study, the GR4J model was used as a benchmark to more objectively evaluate the performance of a semi-distributed model. The model was only applied when considering unregulated (naturalized) flows.

\section{III.2.The semi-distributed TGR model}

A semi-distributed model called TGR (Munier, 2009; Lerat et al., 2012) was implemented to more closely account for the heterogeneity of the basin (see schematic diagram in Figure 3). The Seine River basin (Figure 1) was divided into 25 sub-basins corresponding to the 25 gauging stations selected. This hydrological splitting created intermediary zones between each pair of consecutive stations along the river reach. Each sub-basin or intermediary zone was first modelled using the GR4J model. Then all the contributions were routed along the channel network to the outlet using a lag and route propagation approach (see e.g. Bentura and Michel, 1997). The hydraulic model used for transferring flows is a first-order transfer function with a constant lag (i.e. not dependent on flow magnitude). The model parameters are pure delay (in hours) and the attenuation coefficient (in hours). The model showed promising results in exploratory tests on the Seine basin (Munier, 2009; Perrin et al., 2009).

210 Each sub-basin has its own parameters. Therefore the calibration is done sequentially, from upstream to downstream. For the sub-basins located at the upstream ends (i.e. no other subbasin is located upstream), the calibration of the sub-basin parameters only consists in calibrating the four GR4J parameters. For the other sub-basins (i.e. the sub-basins that route flows from upstream sub-basins), there are two hydraulic parameters plus one extra parameter

215 for the routing of each upstream flow. This extra parameter is used for defining the relative routing distances between the sub-basin outlet and each connected upstream sub-basin outlet.

The model was first used to simulate natural flows. Then the four reservoirs were explicitly included in the TGR model structure to account for their influence. This modified model uses the same calibration as for natural flows. The four reservoirs were included by adding seven new connection points on the hydrographic network (at least two for each bypassing reservoir and 
Author-produced version of the article published in International Journal of River Basin Management JRBM, 2014, N¹2(3), p. 265-283. The original publication is available at http://www.tandfonline.com

Doi: $10.1080 / 15715124.2013 .865636$

one for the run-of-the-river reservoir) corresponding to the position of the reservoir inlets and outlets. For these new stations, the flow is calculated using the parameters of the sub-basin they belong to. These parameters also take into account the size of the sub-basin corresponding to these new stations and the distance to the downstream and upstream gauging stations. Hence the TGR model could explicitly account for the reservoir management rules.

\section{III.3.Assessment methodology}

\section{III.3.a. Calibration and evaluation of hydrological models}

Model performance was evaluated over the entire available observation record by applying the classical split sample test (Klemes, 1986). The 1961-2009 observation period was split into two sub-periods P1 (1961-1984) and P2 (1985-2009). First, P1 was used for calibration and P2 was used for validation; then the roles of P1 and P2 were reversed. The results were evaluated on the two validation periods aggregated together.

Several efficiency measures were used to evaluate the performance of the models under current conditions. C2MQ is a bounded version (see Mathevet et al., 2006) of the Nash and Sutcliffe (1970) criterion (NSQ) calculated on discharge:

$$
C 2 M Q=\frac{N S Q}{2-N S Q}
$$

with $\quad N S Q=1-\frac{\sum_{i=1}^{n}\left(Q_{o, i}-Q_{s, i}\right)^{2}}{\sum_{i=1}^{n}\left(Q_{o, i}-\overline{Q_{o}}\right)^{2}}$

and $\quad \overline{Q_{o}}=\frac{1}{n} \sum_{i=1}^{n} Q_{o, i}$

in which $Q_{o, i}\left(\mathrm{~m}^{3} / \mathrm{s}\right)$ and $Q_{s, i}\left(\mathrm{~m}^{3} / \mathrm{s}\right)$ are the observed and simulated flows at time step $i$, and $n$ is

240 the number of time steps over the test period. This criterion emphasizes the capacity of the model to simulate high flow. A perfect score is obtained for $\mathrm{C} 2 \mathrm{MQ}=1$, and a negative score indicates worse performance than a constant simulation equal to the mean observed discharge. 
Author-produced version of the article published in International Journal of River Basin Management JRBM, 2014, N¹2(3), p. 265-283. The original publication is available at http://www.tandfonline.com

Doi: 10.1080/15715124.2013.865636

Two other criteria based on the same formula as C2MQ were used: C2MLnQ and C2MIQ, which are computed using log-transformed and inverse-transformed streamflows, respectively. They emphasize model performance on low and very low flows, respectively (see Pushpalatha et al., 2012). Efficiency criteria were calculated using naturalized flows at each gauging station when reservoirs are not accounted for in the models and using observed (regulated) flows in the case of the TGR model evaluation with reservoirs. Note that the Nash-Sutcliffe efficiency index was also used for the evaluation of simulated time series of volumes stored in the reservoirs and will be noted NSV in this case.

After model evaluation, the whole reference period was calibrated using available data and calibrated parameters were used to simulate flows over the present and future periods using input data simulated by climate models.

\section{III.3.b. Hydrological descriptors}

255 The trends between future and present climate conditions were assessed using a set of hydrological descriptors. Mean discharge was the basic primary descriptor considered. Two others focus on low flows:

- the annual minimum monthly flow with a 5-year return period, noted QMNA5 $\left(\mathrm{m}^{3} / \mathrm{s}\right)$. The lowest monthly flow is selected for each year and a log-normal distribution is adjusted and used to compute the target variable.

- the $95^{\text {th }}$ percentile flow of the flow duration curve, noted Q95 $\left(\mathrm{m}^{3} / \mathrm{s}\right)$. It is determined by ranking all daily discharge values and finding the discharge value exceeded $95 \%$ of the time.

The last two descriptors characterize high flows:

- the annual daily maximum flow with a 10-year return period, noted QJXA10 $\left(\mathrm{m}^{3} / \mathrm{s}\right)$. The largest daily flow is selected for each year and a Gumbel distribution is adjusted and used to compute the target variable.

- the $10^{\text {th }}$ percentile flow, noted $\mathrm{Q} 10\left(\mathrm{~m}^{3} / \mathrm{s}\right)$. It is determined by ranking all daily discharge values and finding the discharge value exceeded $10 \%$ of the time.

270 For each hydrological descriptor $h d$, a relative evolution $\Delta(\%)$ between present and future conditions was calculated by: 


$$
\Delta=\frac{h d(\text { future })-h d(\text { past })}{h d(\text { past })} * 100
$$

\section{III.3.c. Efficiency criteria for reservoir management}

To evaluate the impact and efficiency of reservoir management, flows are monitored at several

275 gauging stations downstream from the four reservoirs. At each gauging station, several thresholds were defined. In low-flow conditions, they are regulatory thresholds used to restrict water uses:

- Vigilance threshold: there is no restriction of water use but the river is highly sensitive to pollution events;

- Alert threshold: $30 \%$ restriction of water use;

- Reinforced alert threshold: $50 \%$ restriction of water use;

- Crisis threshold: the use of water is prohibited except a minimum use for drinking water. For high-flow conditions, the thresholds correspond approximately to three critical levels, respectively: bankfull discharge, frequently flooded areas and exceptionally flooded areas. The monitoring stations and their thresholds are detailed in Table 2. All thresholds were chosen in agreement with the operational services responsible for low-flow and flood management on the basin.

Reservoir management intends to maintain downstream flows within the limits defined by the threshold, i.e. above the low-flow thresholds and below the high-flow thresholds. Hence the efficiency of the reservoir management can be evaluated based on two sets of conditions at the target downstream station: the set of satisfactory cases, noted $S$, when flow at the station remains within the limits defined by the thresholds, and the set of failures, noted $F$, when flow is outside these limits.

The failure rate can be defined as the complementary of reliability. Reliability is the probability

295 for flow $Q_{i}$ at time $i$ to be in the satisfactory state $S$ (Hashimoto et al., 1982). Hence, the failure rate $f r$ is defined as:

$$
f r=1-\operatorname{Prob}\left[Q_{i} \in S\right]
$$


Author-produced version of the article published in International Journal of River Basin Management JRBM, 2014, N¹2(3), p. 265-283. The original publication is available at http://www.tandfonline.com

Doi: $10.1080 / 15715124.2013 .865636$

A failure event is defined by the consecutive days when $Q_{i}$ is in the failure state. The frequency of a failure event is equal to:

$$
\text { freq }=\frac{365,25 j}{n}
$$

where freq is the frequency in years ${ }^{-1}, n$ is the number of days of the study period and $j$ the number of failure events during the period.

We also used the average length of a failure period defined by:

$$
d_{\text {mean }}=\frac{1}{j} \sum_{t=1}^{j} d(t)
$$

305 where $d(t)$ is the duration of the $t^{\text {th }}$ failure period.

Last, we used the vulnerability indicators defined by Kjeldsen and Rosbjerg (2004). In case the reservoir management fails to maintain downstream flow under a high-flow threshold (respectively, above a low-flow threshold), vulnerability is defined as the volume that should have been taken (respectively, released) by the reservoirs to avoid this situation during the event considered. This can be calculated for each failure event. Here we used three statistical indicators calculated from the set of the vulnerability values computed for all the events: (1) the mean value, $\mathrm{VuI}_{\mathrm{Mean}}$ (2) the maximum value, $\mathrm{Vul}_{\mathrm{Max}}$, and (3) the value of the $90^{\text {th }}$ percentile of the distribution of vulnerabilities, $\mathrm{Vul}_{90}$.

\section{Results}

\section{IV.1. Future climate trends}

Figure 4 shows the monthly averages of precipitation, $\mathrm{P}$, temperature, $\mathrm{T}$, and potential evapotranspiration, $\mathrm{PE}$, for the future period over the basin. They can be compared to the monthly observed averages (dashed lines) on the reference period. Due to the bias correction by QQ mapping, the seven climate projections have the same averages as the observations for the present period. Consequently, Figure 4 also provides information about the evolution of the climate variables between present and future. 
Author-produced version of the article published in International Journal of River Basin Management JRBM, 2014, N¹2(3), p. 265-283. The original publication is available at http://www.tandfonline.com

Doi: 10.1080/15715124.2013.865636

Figure 4 clearly shows that all scenarios agree on an increase of temperature and potential evapotranspiration. This increase seems almost constant throughout the year for temperature, and slightly greater in summer than in winter for potential evapotranspiration. The trend for precipitation is less clear. The variability between projections shows substantial uncertainty. However, most models agree on a decrease of precipitation between May and September, while the models diverge for the winter period.

\section{IV.2. Results in natural conditions}

\section{IV.2.a. Model performance in current conditions}

330 The models without the reservoir module were fed with observed data and their outputs were compared to naturalized discharges. The results are presented for each of the 25 stations and for both models in Figure 5. Except for one station (the Grand Morin at Montry, station 18), C2MQ and C2MLnQ criteria are larger than 0.6. The average performance of the 25 stations is quite satisfactory: the two models simulated the hydrological behaviour of the catchments quite

335 well, including low-flow periods. The performance of the two models seems similar for high flows: the difference of $\mathrm{C} 2 \mathrm{MQ}$ between the two models is larger than 0.04 for only four stations and the mean C2MQ criteria over the whole catchment set are very close. For low flows, TGR performs slightly better on average and the difference between TGR and GR4J is larger than 0.05 for five stations. The better performance of TGR for low flows is even more pronounced with the

340 C2MIQ score. However, the level of efficiency for the two models using this score indicates that the low-flow simulation remains difficult on the basin.

The overall better performance of TGR compared to the simpler model GR4J considered as a benchmark is reassuring and gives some confidence in its use. Note that for some upstream stations (for instance stations \#7, 8, 9 and 10), the relatively poor performance can partly be attributed to the low precision of the available runoff data: the naturalized runoff data have a precision of only $0.1 \mathrm{~m}^{3} / \mathrm{s}$, which is quite limited for the very low flows of some rivers. The performance on station \#18 (Grand Morin at Montry), which was the worst for both models, may be partly due to erroneous runoff data: during some periods, the observed runoff was suspiciously null in spite of rainfall events.

350 Figure 6 gives an illustration of the performance of the TGR model on two example stations, the Seine River at Paris-Austerlitz (station \#5, Figure 6a) which is the main outlet, and the Aube River 
Author-produced version of the article published in International Journal of River Basin Management JRBM, 2014, N¹2(3), p. 265-283. The original publication is available at http://www.tandfonline.com

Doi: 10.1080/15715124.2013.865636

at Arcis-sur-Aube (station \#24, Figure 6b), which is more directly impacted by management dam. The graphs show the mean daily flow values for each calendar day over the 1991-2008 period. It can be seen (purple lines) that the model manages to reproduce quite well catchment behaviour

355 in natural conditions on these examples. The curves for influenced flows will be discussed in section IV.3.a.

\section{IV.2.b. Hydrological simulations using simulated climatic inputs}

The hydrological simulations based on simulated climate inputs were analysed in relative terms, as the relative evolution of selected hydrological descriptors between PST and FUT periods. 360 Here, the impacts of dams were not taken into account in the hydrological models and catchments are considered to be unregulated. Figure 7 shows the relative evolution $(\Delta)$ of the mean annual discharge, QMNA5, Q95, QJXA10, Q10 (Figure 7a) and the mean monthly discharges (Figure 7b). In this figure, the 14 simulations (i.e. the two hydrological models forced by the seven climate simulations) for the 25 stations are analysed altogether.

365 The decrease in QMNA5 and Q95 (low flows) is the most striking result of Figure 7a. This decrease is observed for all 14 simulations on the 25 stations. More than $75 \%$ of them show a decrease greater than 25\%. This evolution of QMNA5 and Q95 is related to the evolution of mean discharge during the dry months of the year (June to November; Figure 7b). These results indicate that the increase of the severity and length (not shown here) of low-flow events may

370 have strong impacts on future reservoir management during summer. This evolution goes along with a possible decrease of mean annual discharge. However, this decrease of annual discharge is less likely: $25 \%$ of the simulations show a slight increase or no trend.

Regarding high flows, the evolutions of QJXA10 and Q10 evolution seem to be uncertain, given the divergence between simulations: some of them show an increase of these hydrological

375 descriptors, while the reverse can also be true for others. Even if QJXA10 values tend to increase, confident conclusions are difficult to draw given that $25 \%$ of the simulations exhibit a decrease. The winter high-flow period also indicates an uncertain evolution of monthly discharge: the simulations diverge and the spread is substantial.

Figure 8 (blue curves) illustrates the evolution of mean daily flows (for each calendar day) 380 between the present (PST) and future (FUT) conditions for the Paris-Austerlitz (Figure 8a) and Arcis-sur-Aube (Figure 8b) stations, already used as examples in Figure 6. For these two stations, 
Author-produced version of the article published in International Journal of River Basin Management JRBM, 2014, N¹2(3), p. 265-283. The original publication is available at http://www.tandfonline.com

Doi: 10.1080/15715124.2013.865636

a quite similar behaviour can be observed, with a decrease of low flows consistent between simulations, and an uncertain evolution on high flows, with large FUT band widths surrounding the PST simulations. The curves for influenced flows will be discussed in section IV.3.d.

\section{IV.3. Results when accounting for the reservoirs influence}

\section{IV.3.a. Performance of the hydrological model in current conditions}

To evaluate the performance of the integrated TGR model (with reservoir modelling), we compared simulated flows with the historical observed flows at the gauging stations (hereafter called observed flows and noted OBS). Since the more recently built reservoir (Aube) has been fully operating only since 1991, the chosen period for this assessment was 1991-2008. The results are presented for each gauging station in Figure 9, except for Trannes (\#01), Chaumard (\#07), Saint-Germain (\#09), Nogent-sur-Seine (\#13) and Montereau (\#15), where observed flows were not available.

$395 \mathrm{C} 2 \mathrm{MQ}$ and C2MLnQ values are higher than 0.6 for all stations except Montry (\#18) and SaintDizier (\#04) for C2MLnQ. The three efficiency criteria, C2MQ, C2MLnQ and C2MIQ, remain quite high at the downstream stations, especially in the Paris area. The performance on low flows is perceptibly decreased compared to results on naturalized flows even on stations upstream from the reservoirs. This can be due to the water withdrawn from the naturalized flows and not 400 simulated in the model.

The flows simulated at the reservoir inlets and the outlets were roughly the same as the observed flows. All NSQ criteria at the inlets were around 0.3 except for the Blaise inlet on the Marne reservoir with a negative NSQ. This reservoir has two inlets on the Marne and Blaise Rivers and the management rules for flow split between these two inlets are not formalized and therefore difficult to mimic. C2MQ and C2MLnQ have positive values (up to 0.48 for the Seine inlet), whereas C2MIQ values are all negative except for the Aube inlet. This poor result in low flows at the inlets can be explained by the way the manager handles the minimum regulatory flow for aquatic life preservation. The rule applied in the model is very crude: when the water demand for filling the reservoir cannot be completely achieved because of the minimum regulatory flow, the model takes all the available water and only leaves the minimum regulatory 
Author-produced version of the article published in International Journal of River Basin Management JRBM, 2014, Nº12(3), p. 265-283. The original publication is available at http://www.tandfonline.com

Doi: 10.1080/15715124.2013.865636

flow in the river. In reality, the management here is much more empirical and the flow left in the river is always greater than the minimum regulatory flow.

Acceptable results were obtained at the reservoir outlets, except for the outlet of the Seine reservoir. This is due to the presence of a hydroelectricity plant at the outlet. The observed flow

415 at the outlet is mostly around $25 \mathrm{~m}^{3} / \mathrm{s}$ for hydropower production. This behaviour is not represented in the management model.

Although the models' performance is not fully satisfactory at the reservoir inlets and outlets, the reservoir volumes are quite well simulated. Performance was assessed with the Nash-Sutcliffe coefficient calculated on stored daily volumes (NSV) and the bias (i.e. the ratio between mean 420 simulated and mean observed volumes), showing good results (see Table 3).

All these indicators at the gauging stations downstream from the reservoirs, at the reservoir inlets and outlets and also on the reservoirs themselves, show that the current management rules correctly mimic the current behaviour of the watershed as it is influenced by the reservoirs, especially in the Paris region. An illustration of TGR simulations for the Paris-

425 Austerlitz and Arcis-sur-Aube stations is shown in Figure 6 (green lines). The model reproduces quite well the influence of dams on flows. The comparison between purple and green curves clearly shows the double effect of dams for low flow augmentation with dam release starting in July and high flow alleviation with flow retention during the wet season. This effect is logically more pronounced at the Arcis-sur-Aube station than at the Paris-Austerlitz station which is much further downstream.

\section{IV.3.b. Performance of the reservoir management in current conditions}

Efficiency criteria relative to low-flow and high-flow thresholds (failure rate, return period, mean duration and vulnerabilities) calculated with simulated and observed flows, respectively, may diverge greatly. This is due to the small number of events occurring in the studied time series 435 (17 years), which partly negates statistically robust estimations. Because of the threshold effect, these indicators are also very sensitive to the period chosen (Loucks, 1997). Kjeldsen and Rosbjerg (2004) have already underlined the problem of the reliability of these indicators for short time periods. The best matches between indicators calculated from observed and simulated flows were found on the first thresholds (bankfull discharge) for high flows (see Figure 
Author-produced version of the article published in International Journal of River Basin Management JRBM, 2014, N¹2(3), p. 265-283. The original publication is available at http://www.tandfonline.com

Doi: 10.1080/15715124.2013.865636

440 10). There was also a perfect match for indicators on the third threshold (exceptional flooding) because no event occurred during the period studied.

These results on efficiency criteria show that significant uncertainty in simulation exists. Therefore, the interpretation of the evolution of these criteria under climate change will have to be considered with caution.

445 In the following sections, we will particularly focus on the three downstream stations in Paris or near the Paris area because of the critical importance of these stations for drinking water supply and flood risk assessment. These stations are i) Alfortville on the Seine River (\#16, 30,800 $\mathrm{km}^{2}$ ) influenced by the Aube, Seine and Pannecière reservoirs, ii) Noisiel on the Marne River (\#17, $12,550 \mathrm{~km}^{2}$ ) influenced by the Marne reservoir and iii) Paris-Austerlitz on the Seine River (\#5,

$45043,800 \mathrm{~km}^{2}$ ) influenced by all four reservoirs. Alfortville and Noisiel are located just upstream from the confluence of the Seine and Marne Rivers.

\section{IV.3.c. Simulations using simulated climate inputs}

The model was run using the seven GCM climate projections over the 1961-1991 period and also under the observed climate condition (hereafter called historical scenario). In both cases, we considered that all reservoirs were fully operating over the whole period. We focused on the distribution of each efficiency criterion obtained from the seven simulations at Paris (see Figure $11)$.

The criteria calculated for the first and second low-flow thresholds (the vigilance and alert thresholds) show that a sufficient number of events occur during the PST periods under both 460 simulated and historical scenarios to be representative. There is a good correlation between criteria calculated in both cases. However, the failure rate and the frequency are systematically a bit larger under the observed climate conditions. Their values are the most often included in the range of the simulations with GCM-based inputs. In terms of duration and impacts (Vul Mean, $\mathrm{VuI}_{\text {Max }}$ and $\mathrm{VuI}_{90}$ ), the differences between the mean value for the GCM scenario and historical scenario are not significant (less than 10\%). However, the range of PST scenario criteria is too wide to consider the median value as representative. The criteria calculated for the two other low-flow thresholds (reinforced alert and crisis threshold) show no significant difference between the median GCM scenario and the historical scenario. Nevertheless, there is substantial 
Author-produced version of the article published in International Journal of River Basin Management JRBM, 2014, N¹2(3), p. 265-283. The original publication is available at http://www.tandfonline.com

Doi: 10.1080/15715124.2013.865636

variability in the GCM scenario criteria due to the insufficient number of events, which means that robust conclusions are difficult to draw.

Similar comments could be made on criteria calculated for the high-flow thresholds. There is a sufficient number of events exceeding the first high-flow threshold. The criteria values calculated for the historical scenario are very similar to the values calculated for the GCM scenarios, although they are a bit higher. Indeed, the failure rate, frequency, mean duration and vulnerability calculated under the observed climatic conditions are also included in the range of the PST scenarios. Events are too rare in the other two high-flow thresholds to draw any conclusions.

This comparison indicates that the frequency, mean duration and vulnerability ( $\mathrm{VuI}_{\mathrm{Mean}}, \mathrm{VuI}_{\mathrm{Max}}$ $\mathrm{Vul}_{90}$ ) of frequent hydrological events are quite well captured by the seven PST scenarios during

480 the period studied. This also proves the usefulness of bias-correction methods applied to PST scenarios. This suggests that it should be possible and relevant to highlight a future tendency on the hydrological conditions on the Seine basin.

\section{IV.3.d. Impact of climate change on the efficiency of the reservoirs using current management rules}

485 The TGR model was run with the seven climate simulations for the PST and FUT periods using current management rules. Average, minimum and maximum evolution of efficiency criteria were used for the analysis of the impact of climate change. The model does not consider water withdrawals and how they may evolve in the future.

To start with, one can have a look at the possible evolution of flow regimes under climate change, when accounting for the combined influence of dams. This is illustrated in Figure 8 (red curves) for the Paris-Austerlitz (Figure 8a) and Arcis-sur-Aube (Figure 8b) stations. The evolution between PST and FUT periods looks quite similar as in non-influenced conditions (blue curves), i.e. consistent decrease of low flows and uncertain evolution of high flows. Interestingly, however, in low flow conditions, a clear gap appears in simulated ranges between PST and FUT periods, stressing the dramatic decrease of low flows between PST and FUT and the difficulty to maintain low flows at present levels with current management rules.

Low-flow conditions 
Author-produced version of the article published in International Journal of River Basin Management JRBM, 2014, N¹2(3), p. 265-283. The original publication is available at http://www.tandfonline.com

Doi: 10.1080/15715124.2013.865636

There were enough events under the vigilance threshold in PST and FUT conditions to obtain significant results. A general worsening of all criteria for the mean evolution of the seven scenarios for all the stations can be noted (see Figure 12, left). The median scenario shows at least a doubling of the failure rate and the frequency at the three downstream stations, while the vulnerability seems to be quite constant. The majority of GCMs scenarios give a clear trend of performance decrease for the vigilance threshold. Moreover, a dramatic failure rate is expected ( $45 \%$ of days) for the worst scenario in FUT period while the maximum vulnerability decreases and the events frequencies move from 3.4 to 4.4 events per year.

At the Paris station, the expected increase of the frequency varies from 0 to 1 event per year and the mean vulnerability will vary from $-13.5 \mathrm{hm}^{3}$ to $+31 \mathrm{hm}^{3}$. The majority of GCM scenarios show a clear trend of decreasing performance for the vigilance threshold.

For the lower low-flow thresholds, only a few events occurred, so their representativeness is

510 limited. Nevertheless, the failure rate and frequency of events increased for all monitoring stations and for almost all scenarios. The trends on the mean duration of the events and vulnerability indicators were not significant.

The analysis on low-flow efficiency criteria shows that in the future, flows under restriction thresholds (i.e. alert, reinforced alert and crisis) will more frequently occur. The crisis threshold,

515 which was only reached during the historical drought of 1976 at Paris, would be frequently reached in the future. In addition, because the withdrawals and their evolution were not taken into account in our study, these results are likely to be too optimistic. It means that climate change could have a major impact on low flows on the basin, and consequently on water uses if management rules remain unchanged. However, the maximum vulnerability at Paris in future conditions for the crisis threshold is about $55 \mathrm{hm}^{3}$, while the mean of the scenarios is about $14 \mathrm{hm}^{3}$. These volumes are quite manageable compared to the total capacity of the four reservoirs $\left(805 \mathrm{hm}^{3}\right)$. Therefore, we can expect that an adaptation of the management rules could realistically improve this critical situation.

\section{High-flow conditions}

525 The results on the vigilance threshold do not show a clear trend for any of the indicators (see Figure 12, right). As for natural conditions, the evolution for the seven scenarios diverges and the evolution of the average behaviour is quite neutral. 
Author-produced version of the article published in International Journal of River Basin Management JRBM, 2014, N¹2(3), p. 265-283. The original publication is available at http://www.tandfonline.com

Doi: 10.1080/15715124.2013.865636

For the three thresholds, the evolution of the vulnerability indicators differs greatly, especially for the Alfortville, Noisiel and Paris stations. This stems particularly from the limited length of 530 the time series and the fact that we are trying to calculate indicators on rare events that may or may not occur in the different GCM scenarios. Note that a major flood is simulated using the GFDL-CM 2.0 scenario in the FUT period, which generates vulnerabilities of $470 \mathrm{hm}^{3}$ and 118 $\mathrm{hm}^{3}$, respectively, for the second and the third thresholds at Paris. This vulnerability is quite high. During this event, the Seine and Pannecière reservoirs are completely filled, $40 \mathrm{hm}^{3}$ are still available in the Marne reservoir, and $180 \mathrm{hm}^{3}$ in the Aube reservoir which is not impacted by this flood. It shows that a centralized controller might be able to mitigate this event by better using the Aube reservoir, which might consequently avoid exceeding the third threshold. Nevertheless, the vulnerability of the second threshold $\left(470 \mathrm{hm}^{3}\right)$ and the volume still available during the flood $\left(220 \mathrm{hm}^{3}\right)$ proves that even with the most optimized reservoir management, 540 this event could not be handled with the current infrastructures.

\section{Discussion and conclusions}

\section{V.1. Main outcomes}

This study investigated the sustainability of current rules applied to the management of artificial multi-objective reservoirs on the Seine River basin. The four large dams are used for low flow augmentation during the summer and autumn season and flood alleviation during winter and spring season. The current management rules based on objective filling curves, though simple, are generally effective to reach the management objectives set by water managers in current climate conditions for common low-flow or drought events.

The model that was set up to simulate the basin hydrological behaviour and the operational 550 dam management was judged quite efficient, though some discrepancies appeared in some cases. In terms of management, it was found sometimes a bit difficult to exactly reproduce the decisions of the dam manager, given that other information that those we had here may be available in practice and used to make decisions.

Using climate simulation from 7 GCMs, we showed that the basin may naturally experience a severe decrease of low flows in the future, while the evolution of high flows seems much more 
Author-produced version of the article published in International Journal of River Basin Management JRBM, 2014, N¹2(3), p. 265-283. The original publication is available at http://www.tandfonline.com

Doi: 10.1080/15715124.2013.865636

uncertain. We selected a set of efficiency criteria to then evaluate the evolution of reservoir management performance between current and future conditions, based on operational lowflow and high-flow warning thresholds. Simulations made by accounting for the influence of reservoirs showed that there could be a dramatic increase of management failures in low-flow conditions in the future if current management rules were kept the same. The situation on high flows would be more contrasted and our results do not indicate clear trends in reservoir efficiency.

\section{V.2. Limitations}

Performance indicators on reservoir management are based on stochastic theories. One major criticism that can be made on these results is the lack of relevance of these indicators when only short time series are available. This makes it difficult to reliably interpret the results for rare events. Longer time series should be generated to reach relevant results for large return periods, e.g. using resampling techniques (Lall and Sharma, 1996). However, these results reveal clear trends in the evolution of low-flow situations and supply particular events in future 570 scenarios that were used as test cases to diagnose the limitations of the current management rules and infrastructures.

The evaluation methodology developed here to evaluate the sustainability of management rules and applied to a complex case study (four dams managed in parallel) is quite general and should be applicable in other conditions. Note however that the implementations of the hydrological model and the management model may be limiting factors in the evaluation approach in case their efficiency is judged too limited. We also noticed that climate simulations cannot be used without a bias-correction step to get sensible results.

This study implicitly made some assumptions (e.g. stationarity of basin hydrological behaviour) and did not account for possible changes in land cover or land use. It also did not account for other influences (e.g. water withdrawals) than dams on flow regime, which may also have a significant impact. For these reasons, the uncertainty associated to our results is probably larger than what was shown here. 
Author-produced version of the article published in International Journal of River Basin Management JRBM, 2014, N¹2(3), p. 265-283. The original publication is available at http://www.tandfonline.com

Doi: 10.1080/15715124.2013.865636

\section{V.3. Perspectives}

To face possible changes on the basin, several adaptation strategies can be suggested to 585 improve the management. First, the exceptional flooding simulated in future conditions suggests that centralized management could improve the situation in case of spatially heterogeneous events over the basin. In this case, the current management is only reactive (feedback control) and because of the propagation time between the reservoirs and the downstream stations, management anticipating (feed-forward control) the events for the downstream stations should improve management efficiency. Last, considering the possible hydrological evolution shown here, with a possible gap in seasonal events, a readjustment of the objective filling curves should be considered.

Further investigations are currently carried out within the Climaware project to identify adaptation strategies to improve reservoir management. A centralized tree-based model 595 predictive control (TB-MPC) of the four reservoirs (Andréassian et al., 2012; Brigode et al., 2013) will be investigated. This method provides downstream discharge forecasts and anticipation of the operations on the reservoirs. Stochastic methods for defining new filling curves adapted to climate change will also be applied (Bader, 1992). The test of real-time management methods under uncertain future is also investigated, using ensemble precipitation forecasts. Results will 600 be reported in due course.

\section{Acknowledgments}

This work was done within the Climaware project coordinated by the University of Kassel (www.uni-kassel.de/fb14/wasserbau/CLIMAWARE/) and funded by the IWRM-Net programme (www.iwrm-net.eu). The authors thank SCHAPI for providing observed flow data, and Météo-

605 France and Cerfacs for providing observed and downscaled climate data. The review comments made by Alain Poirel and another anonymous reviewer on the manuscript were helpful to clarify and improve the manuscript and are gratefully acknowledged. 
Author-produced version of the article published in International Journal of River Basin Management JRBM, 2014, N¹2(3), p. 265-283. The original publication is available at $\mathrm{http}: / / \mathrm{www}$.tandfonline.com

Doi: 10.1080/15715124.2013.865636

\section{References}

610 Ambroise-Rendu, M. (1997). 1910 : La Seine en crue paralyse la capitale La Houille Blanche,(8): 40-44.

Andréassian, V., N. Le Moine, C. Perrin, M. H. Ramos, L. Oudin, T. Mathevet, J. Lerat and L. Berthet (2012). All that glitters is not gold: The case of calibrating hydrological models. Hydrological Processes, 26(14): 2206-2210.

615 Bader, J. C. (1992). Multiple use management of Manantali Dam: determination of limiting storage levels. Hydrologie Continentale, 7(1): 3-12.

Bentura, P. L. F. and C. Michel (1997). Flood routing in a wide channel with a quadratic lag-androute method. Hydrological Sciences Journal, 42(2): 169-189.

Boe, J., L. Terray, F. Habets and E. Martin (2007). Statistical and dynamical downscaling of the

620 Seine basin climate for hydro-meteorological studies. International Journal of Climatology, 27(12): 1643-1655.

Boé, J., L. Terray, F. Habets and E. Martin (2006). A simple statistical-dynamical downscaling scheme based on weather types and conditional resampling. Journal of Geophysical Research: Atmospheres, 111(D23): D23106.

625 Boé, J., L. Terray, E. Martin and F. Habets (2009). Projected changes in components of the hydrological cycle in French river basins during the 21st century. Water Resources Research, 45: W08426.

Brigode, P., L. Oudin and C. Perrin (2013). Hydrological model parameter instability: A source of additional uncertainty in estimating the hydrological impacts of climate change? Journal of 630 Hydrology, 476: 410-425.

Chauveau, M., S. Chazot, C. Perrin, P. Y. Bourgin, E. Sauquet, J. P. Vidal, N. Rouchy, E. Martin, J. David, T. Norotte, P. Maugis and X. de Lacaze (2013). Quels impacts des changements climatiques sur les eaux de surface en France à I'horizon 2070 ? La Houille Blanche,(4): (in press). Doll, P. and K. Fiedler (2008). Global-scale modeling of groundwater recharge. Hydrology and

635 Earth System Sciences, 12(3): 863-885.

Ducharne, A., C. Baubion, N. Beaudoin, M. Benoit, G. Billen, N. Brisson, J. Garnier, H. Kieken, S. Lebonvallet, E. Ledoux, B. Mary, C. Mignolet, X. Poux, E. Sauboua, C. Schott, S. Thery and P. Viennot (2007). Long term prospective of the Seine River system: Confronting climatic and direct anthropogenic changes. Science of the Total Environment, 375(1-3): 292-311.

640 Ducharne, A., É. Sauquet, F. Habets, M. Déqué, S. Gascoin, A. Hachour, E. Martin, C. Pagé, L. Terray, D. Thiéry and P. Viennot (2011). Évolution potentielle du régime des crues de la Seine sous changement climatique. La Houille Blanche,(1): 51-57.

Eum, H.-I. and S. P. Simonovic (2010). Integrated Reservoir Management System for Adaptation to Climate Change: The Nakdong River Basin in Korea. Water Resources Management, 24(13):

645 3397-3417.

Georgakakos, A. P., H. Yao, M. Kistenmacher, K. P. Georgakakos, N. E. Graham, F. Y. Cheng, C. Spencer and E. Shamir (2012). Value of adaptive water resources management in Northern California under climatic variability and change: Reservoir management. Journal of Hydrology, 412: 34-46.

650 Gudmundsson, L., J. B. Bremnes, J. E. Haugen and T. Engen-Skaugen (2012). Technical Note: Downscaling RCM precipitation to the station scale using statistical transformations - a comparison of methods. Hydrology and Earth System Sciences, 16(9): 3383-3390. 
Author-produced version of the article published in International Journal of River Basin Management JRBM, 2014, N¹2(3), p. 265-283. The original publication is available at $\mathrm{http}: / / \mathrm{www}$.tandfonline.com

Doi: 10.1080/15715124.2013.865636

Hashimoto, T., J. R. Stedinger and D. P. Loucks (1982). Reliability, resiliency, and vulnerability criteria for water resource system performance evaluation. Water Resources Research, 18(1):

14-20.

Hydratec (2011). Actualisation de la base de données des débits journaliers naturalisés (Update of the naturalized daily streamflow database), Rapport d'étude, Les Grands Lacs de Seine.

IPCC (2007). Contribution of Working Groups I, II and III to the Fourth Assessment Report of the Intergovernmental Panel on Climate Change from http://www.ipcc.ch/pdf/assessmentreport/ar4/syr/ar4 syr.pdf, 104.

Kjeldsen, T. R. and D. Rosbjerg (2004). Choice of reliability, resilience and vulnerability estimators for risk assessments of water resources systems. Hydrological Sciences JournalJournal Des Sciences Hydrologiques, 49(5): 755-767.

Klemes, V. (1986). OPERATIONAL TESTING OF HYDROLOGICAL SIMULATION-MODELS.

665 Hydrological Sciences Journal-Journal Des Sciences Hydrologiques, 31(1): 13-24.

Lall, U. and A. Sharma (1996). A nearest neighbor bootstrap for resampling hydrologic time series. Water Resources Research, 32(3): 679-693.

Lerat, J., C. Perrin, V. Andreassian, C. Loumagne and P. Ribstein (2012). Towards robust methods to couple lumped rainfall-runoff models and hydraulic models: A sensitivity analysis on the

670 Illinois River. Journal of Hydrology, 418: 123-135, doi:110.1016/j.jhydrol.2009.1009.1019.

Loucks, D. P. (1997). Quantifying trends in system sustainability. Hydrological Sciences Journal, 42(4): 513-530.

Mathevet, T., C. Michel, V. Andreassian and C. Perrin (2006). A bounded version of the NashSutcliffe criterion for better model assessment on large sets of basins. V. Andreassian, A. Hall, N.

675 Chahinian and J. Schaake, 211-219.

Moulin, L., C. Perrin, C. Michel and V. Andreassian (2005). Taking into account water storage data in a lumped rainfall-runoff model: case study on the Seine basin. Houille Blanche-Revue Internationale De L Eau,(5): 79-87.

Munier, S. (2009). Modélisation intégrée des écoulements pour la gestion en temps réel d'un

680 bassin versant anthropisé. PhD Thesis, Cemagref Montpellier.

Nash, J. E. and J. V. Sutcliffe (1970). River flow forecasting through conceptual models part I - A discussion of principles. Journal of Hydrology, 10(3): 282-290.

Oni, S. K., P. J. Dillon, R. A. Metcalfe and M. N. Futter (2012). Dynamic Modelling of the Impact of Climate Change and Power Flow Management Options using STELLA: Application to the Steephill

685 Falls Reservoir, Ontario, Canada. Canadian Water Resources Journal, 37(2): 125-148.

Panofsky, H. A. and G. W. Brier (1968). Some applications of statistics to meteorology. State College, the Pennsylvania State University Press, 268.

Penman, H. L. (1948). Natural evaporation from open water, bare soil and grass. Proceedings of the Royal Society of London, 193: 120-145.

690 Perrin, C., L. Coron, T. C. Fortier-Filion, S. Munier, X. Litrico, L. Berthet, J. Lerat, J. Peschard, P. Javelle and V. Andréassian (2009). Analyse et modélisation des sous-bassins amont du bassin de la Seine, Cemagref, UR HBAN (Antony) et UMR G-Eau (Montpellier), DIREN Ile-de-France, 76.

Perrin, C., C. Michel and V. Andreassian (2003). Improvement of a parsimonious model for streamflow simulation. Journal of Hydrology, 279(1-4): 275-289.

695 Pushpalatha, R., C. Perrin, N. Le Moine and V. Andreassian (2012). A review of efficiency criteria suitable for evaluating low-flow simulations. Journal of Hydrology, 420: 171-182.

Quintana Segui, P., A. Ribes, E. Martin, F. Habets and J. Boe (2010). Comparison of three downscaling methods in simulating the impact of climate change on the hydrology of Mediterranean basins. Journal of Hydrology, 383(1-2): 111-124. 
Author-produced version of the article published in International Journal of River Basin Management JRBM, 2014, N¹2(3), p. 265-283. The original publication is available at http://www.tandfonline.com

Doi: $10.1080 / 15715124.2013 .865636$

700 Slavik, I. and W. Uhl (2009). Analysing water quality changes due to reservoir management and climate change for optimization of drinking water treatment. Water Science and Technology: Water Supply, 9(1): 99-105.

Teutschbein, C. and J. Seibert (2012). Bias correction of regional climate model simulations for hydrological climate-change impact studies: Review and evaluation of different methods.

705 Journal of Hydrology, 456: 12-29.

Valéry, A. (2010). Modélisation précipitations - débit sous influence nivale. Élaboration d'un module neige et évaluation sur 380 bassins versants. PhD Thesis, Cemagref (Antony), AgroParisTech (Paris).

Vidal, J. P., E. Martin, L. Franchisteguy, M. Baillon and J. M. Soubeyroux (2010). A 50-year high-

710 resolution atmospheric reanalysis over France with the Safran system. International Journal of Climatology, 30(11): 1627-1644. 
Author-produced version of the article published in International Journal of River Basin Management JRBM, 2014, N¹2(3), p. 265-283. The original publication is available at http://www.tandfonline.com

Doi: 10.1080/15715124.2013.865636

\section{List of tables}

715 Table 1: List and characteristics of the 25 target gauging stations on the Seine River basin........28

Table 2: Monitoring stations downstream from the reservoirs, influence of the reservoirs ( $\mathrm{A}=$ Aube, $\mathrm{M}=$ Marne, $\mathrm{P}=$ Pannecière, $\mathrm{S}=$ Seine) and low-flow and high-flow thresholds.... 29

Table 3: Nash-Sutcliffe coefficient (NSV) and bias calculated on daily volumes for the four reservoirs.... 
Author-produced version of the article published in International Journal of River Basin Management JRBM, 2014, N¹2(3), p. 265-283. The original publication is available at http://www.tandfonline.com

Doi: 10.1080/15715124.2013.865636

Table 1: List and characteristics of the $\mathbf{2 5}$ target gauging stations on the Seine River basin

\begin{tabular}{|c|c|c|c|c|}
\hline \# & River name / station name & Hydro code & $\begin{array}{l}\text { Catchment } \\
\text { area }\left(\mathrm{km}^{2}\right)\end{array}$ & $\begin{array}{l}\text { Influenced by } \\
\text { reservoirs }\end{array}$ \\
\hline 01 & Aube / Trannes & - & 1,550 & - \\
\hline 02 & Yonne / Gurgy & $\mathrm{H} 2221010$ & 3,800 & Pannecière \\
\hline 03 & Armançon / Brienon-sur-Armançon & H2482010 & 3,000 & - \\
\hline 04 & Marne / Saint-Dizier & H5071010 & 2,350 & Marne \\
\hline 05 & Seine / Paris & H5920010 & 43,800 & $\begin{array}{l}\text { Seine + Aube + } \\
\text { Marne + Pannecière }\end{array}$ \\
\hline 06 & Seine / Bar-sur-Seine & H0400010 & 2,300 & - \\
\hline 07 & Yonne / Chaumard & - & 200 & Pannecière \\
\hline 08 & Cousin / Cussy-les-Forges & $\mathrm{H} 2172310$ & 250 & - \\
\hline 09 & Cure / St-Germain & - & 400 & - \\
\hline 10 & Serein / Guillon & $\mathrm{H} 2322020$ & 500 & - \\
\hline 11 & Armançon / Aisy-sur-Armançon & $\mathrm{H} 2452020$ & 1,350 & - \\
\hline 12 & Serein / Chablis & H2342010 & 1,100 & - \\
\hline 13 & Seine / Nogent-sur-Seine & - & 9,200 & Seine + Aube \\
\hline 14 & Loing / Épisy & H3621010 & 3,900 & - \\
\hline 15 & Seine / Montereau & - & 21,200 & \begin{tabular}{|l|}
$\begin{array}{l}\text { Seine }+ \text { Aube }+ \\
\text { Pannecière }\end{array}$ \\
\end{tabular} \\
\hline 16 & Seine / Alfortville & H4340020 & 30,800 & $\begin{array}{l}\text { Seine + Aube + } \\
\text { Pannecière }\end{array}$ \\
\hline 17 & Marne / Noisiel & H5841010 & 12,550 & Marne \\
\hline 18 & Grand Morin / Montry & H5752020 & 1,200 & - \\
\hline 19 & Blaise / Louvemont & H5083050 & 450 & - \\
\hline 20 & Voire / Lassicourt & $\mathrm{H} 1362010$ & 900 & - \\
\hline 21 & Marne / Châlons-sur-Marne & H5201010 & 6,300 & Marne \\
\hline 22 & Seine / Méry-sur-Seine & H0810010 & 3,600 & Seine \\
\hline 23 & Yonne / Courlon-sur-Yonne & $\mathrm{H} 2721010$ & 10,700 & Pannecière \\
\hline 24 & Aube / Arcis-sur-Aube & $\mathrm{H} 1501010$ & 3,600 & Marne \\
\hline 25 & Saulx / Vitry-en-Perthois & H5172010 & 2,100 & - \\
\hline
\end{tabular}


Author-produced version of the article published in International Journal of River Basin Management JRBM, 2014, N¹2(3), p. 265-283. The original publication is available at http://www.tandfonline.com

Doi: 10.1080/15715124.2013.865636

Table 2: Monitoring stations downstream from the reservoirs, influence of the reservoirs

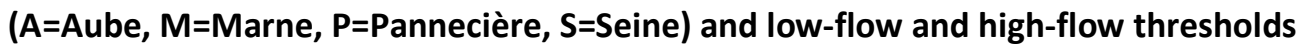

\begin{tabular}{|c|c|c|c|c|c|c|c|c|c|c|}
\hline \multicolumn{4}{|c|}{ Monitoring stations } & \multicolumn{4}{|c|}{$\begin{array}{l}\text { Low-flow thresholds } \\
\qquad\left(\mathrm{m}^{3} / \mathrm{s}\right)\end{array}$} & \multicolumn{3}{|c|}{$\begin{array}{c}\text { High-flow } \\
\text { thresholds }\left(\mathrm{m}^{3} / \mathrm{s}\right)\end{array}$} \\
\hline$\#$ & Gauging station & River & $\begin{array}{l}\text { Influenced by } \\
\text { Reservoirs... }\end{array}$ & 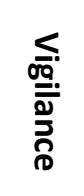 & $\frac{\frac{D}{1}}{7}$ & 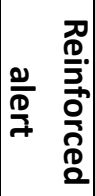 & $\frac{n}{\frac{n}{n}}$ & 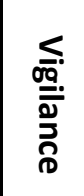 & 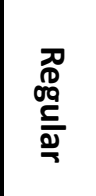 & 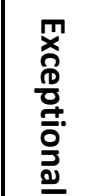 \\
\hline 24 & Arcis-sur-Aube & Aube & $A$ & 6.3 & 5.0 & 4.0 & 3.5 & 110 & 260 & 400 \\
\hline 22 & Méry-sur-Seine & Seine & $S$ & 7.3 & 5.0 & 4.0 & 3.5 & 140 & 170 & 400 \\
\hline 13 & Nogent-sur-Seine & Seine & $A+S$ & 25.0 & 20.0 & 17.0 & 16.0 & 180 & 280 & 420 \\
\hline 02 & Gurgy & Yonne & $P$ & 14.0 & 12.5 & 11.0 & 9.2 & 220 & 340 & 400 \\
\hline 23 & Courlon-sur-Yonne & Yonne & $P$ & 23.0 & 16.0 & 13.0 & 11.0 & 550 & 700 & 900 \\
\hline 16 & Alfortville & Seine & $A+S+P$ & 64.0 & 48.0 & 41.0 & 36.0 & 850 & 1200 & 1400 \\
\hline 21 & Châlons-sur-Marne & Marne & $M$ & 12.0 & 11.0 & 9.0 & 8.0 & 330 & 520 & 700 \\
\hline 17 & Noisiel & Marne & $M$ & 32.0 & 23.0 & 20.0 & 17.0 & 350 & 500 & 650 \\
\hline 05 & Paris & Seine & $A+S+P+M$ & 81.0 & 60.0 & 51.0 & 45.0 & 950 & 1600 & 2000 \\
\hline
\end{tabular}


Author-produced version of the article published in International Journal of River Basin Management JRBM, 2014, N¹2(3), p. 265-283. The original publication is available at http://www.tandfonline.com

Doi: 10.1080/15715124.2013.865636

Table 3: Nash-Sutcliffe coefficient (NSV) and bias calculated on daily volumes for the four reservoirs

735

\begin{tabular}{|l|c|c|}
\hline Reservoir & NSV & Bias (\%) \\
\hline Aube & 0.96 & -1.13 \\
\hline Seine & 0.80 & -0.55 \\
\hline Pannecière & 0.54 & -5.50 \\
\hline Marne & 0.68 & +0.91 \\
\hline
\end{tabular}


Author-produced version of the article published in International Journal of River Basin Management JRBM, 2014, N¹2(3), p. 265-283. The original publication is available at $\mathrm{http}: / / \mathrm{www}$.tandfonline.com

Doi: 10.1080/15715124.2013.865636

\section{List of Figures}

740 Figure 1: Contour map of the Seine River basin at Paris, with gauging stations, main hydrographic network and reservoirs

Figure 2: Monthly average of precipitation, temperature and potential evapotranspiration variables over the PST period (1961-1991) for the Seine River basin at Paris. The dashed lines represent SAFRAN observations and the coloured lines are the seven downscaled climate simulations without bias correction 34

Figure 3: Schematic representation of the TGR model implementation for six gauging stations, coupling hydrological modelling of the upstream and intermediary basins and hydraulic routing (Adapted from Munier, 2009). 35

Figure 4: Monthly average of precipitation, temperature and potential evapotranspiration over 750 the FUT period (2046-2065) for the Seine River basin at Paris. The dashed lines represent SAFRAN observations over the reference period and the coloured lines are the seven downscaled and bias-corrected climate simulations. 36

Figure 5: Efficiency criteria in validation (top: C2MQ; middle: C2MLnQ; bottom: CMIQ) obtained by the GR4J (left) and TGR (right) models in current conditions considering naturalized flows for

Figure 6: Mean daily flows for (a) the Seine River at Paris-Austerlitz and (b) the Aube River at Arcis-sur-Aube. Influenced and naturalized flows are shown for the 1991-2008 period. Simulations are produced by the TGR model in validation. 38

Figure 7: (a) Evolution $(\Delta)$ of the hydrological descriptors computed by the two hydrological models using the seven climate simulations on the 25 stations. The boxplots show the 5, 25, 50, 75 , and $95 \%$ percentiles of the 14 simulations. (b) Evolution $(\Delta)$ of the monthly discharge for the 14 simulations. 39

Figure 8: Evolution of daily mean discharge between present (PST) and future (FUT) conditions at (a) the Seine River at Paris-Austerlitz and (b) the Aube River at Arcis-sur-Aube. Discharge simulations are obtained using the TGR model run with the 7 climate simulations. The shaded colours represent the band widths of the 7 simulations. Discharge simulations are shown in natural and influenced conditions.

Figure 9: Efficiency criteria (top: $C 2 M Q$; middle: $C 2 M L n Q$; bottom: CMIQ) obtained by the integrated TGR model (accounting for reservoirs) in current conditions considering observed flows for the 25 gauging stations (in grey, stations where observed flows were not available). .41

Figure 10: Efficiency criteria (a: event frequency; b: failure rate; c: maximum vulnerability) for the thresholds in low-flow (left) and high-flow (right) conditions using the observed (black dots) 
Author-produced version of the article published in International Journal of River Basin Management JRBM, 2014, N¹2(3), p. 265-283. The original publication is available at http://www.tandfonline.com

Doi: 10.1080/15715124.2013.865636

and simulated (white dots) flows under historical climate conditions (1991-2008) for all the monitoring stations. 42

775 Figure 11: Efficiency criteria (a: event frequency; b: failure rate; c: maximum vulnerability) for the thresholds in low-flow (left) and high-flow (right) conditions at Paris using the observed climate data (black dots) and the seven simulated climate data (grey bars) over the PST period (1961-1991) .43

Figure 12: Efficiency criteria (a: event frequency; b: failure rate; c: maximum vulnerability) for the thresholds in low-flow (left) and high-flow (right) conditions under present and future conditions using the seven climate simulations for all monitoring stations.... 
Author-produced version of the article published in International Journal of River Basin Management JRBM, 2014, N¹2(3), p. 265-283. The original publication is available at http://www.tandfonline.com

Doi: $10.1080 / 15715124.2013 .865636$

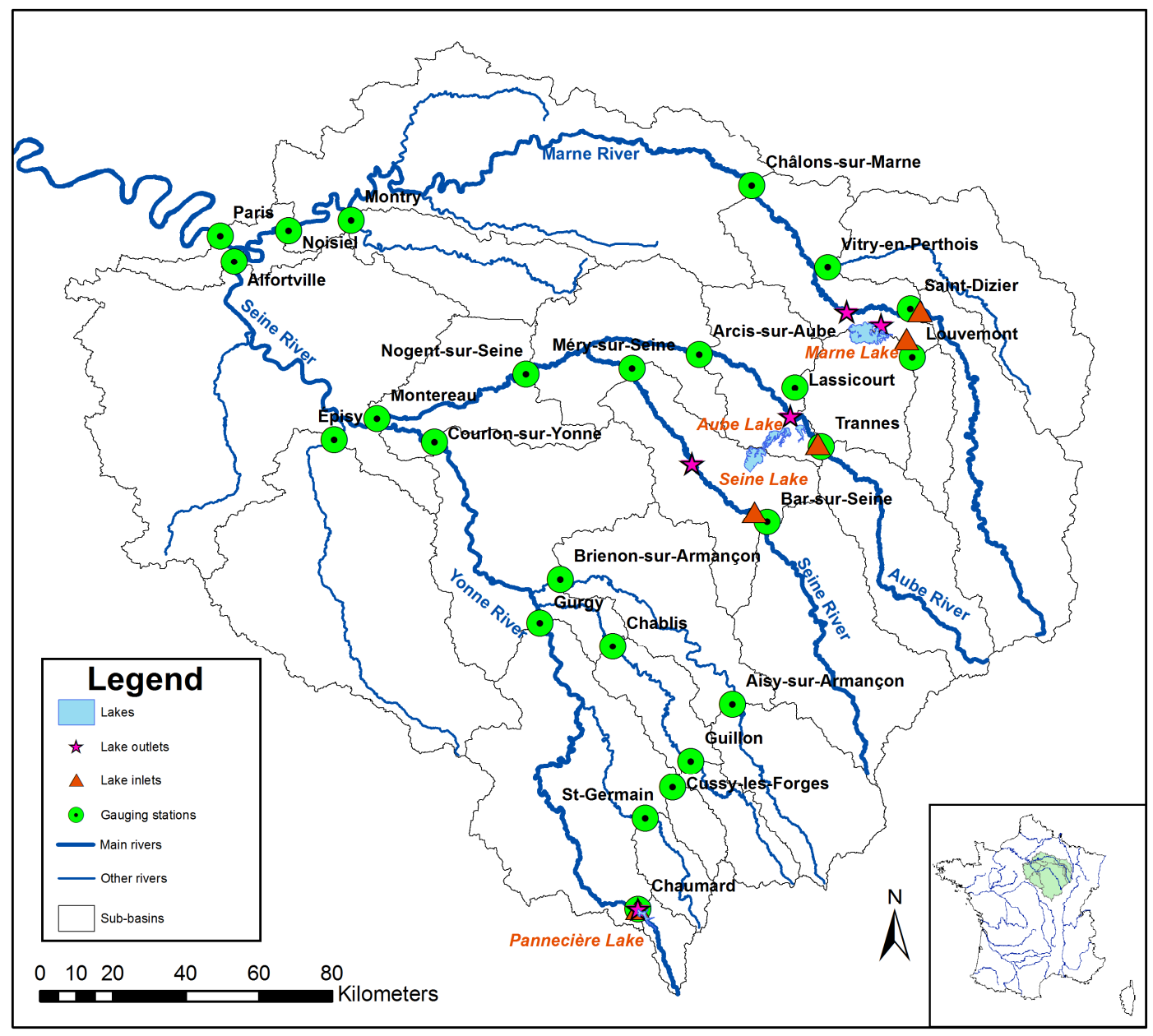

785 Figure 1: Contour map of the Seine River basin at Paris, with gauging stations, main hydrographic network and reservoirs 

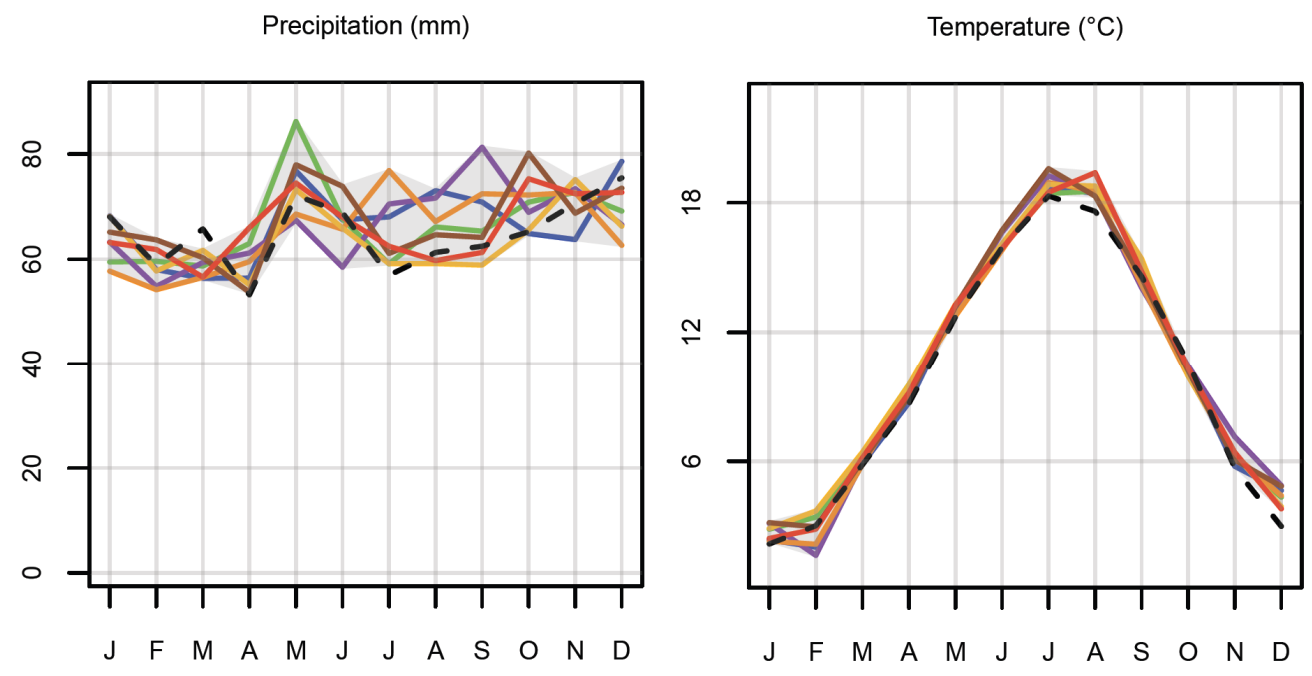

PE (mm)

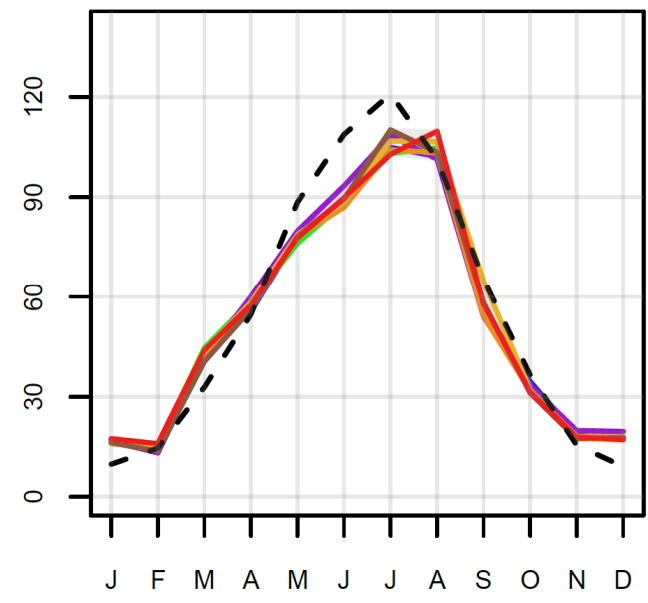

Figure 2: Monthly average of precipitation, temperature and potential evapotranspiration variables over the PST period (1961-1991) for the Seine River basin at Paris. The dashed lines represent SAFRAN observations and the coloured lines are the seven downscaled climate simulations without bias correction. 
Author-produced version of the article published in International Journal of River Basin Management JRBM, 2014, N¹2(3), p. 265-283. The original publication is available at http://www.tandfonline.com

Doi: 10.1080/15715124.2013.865636

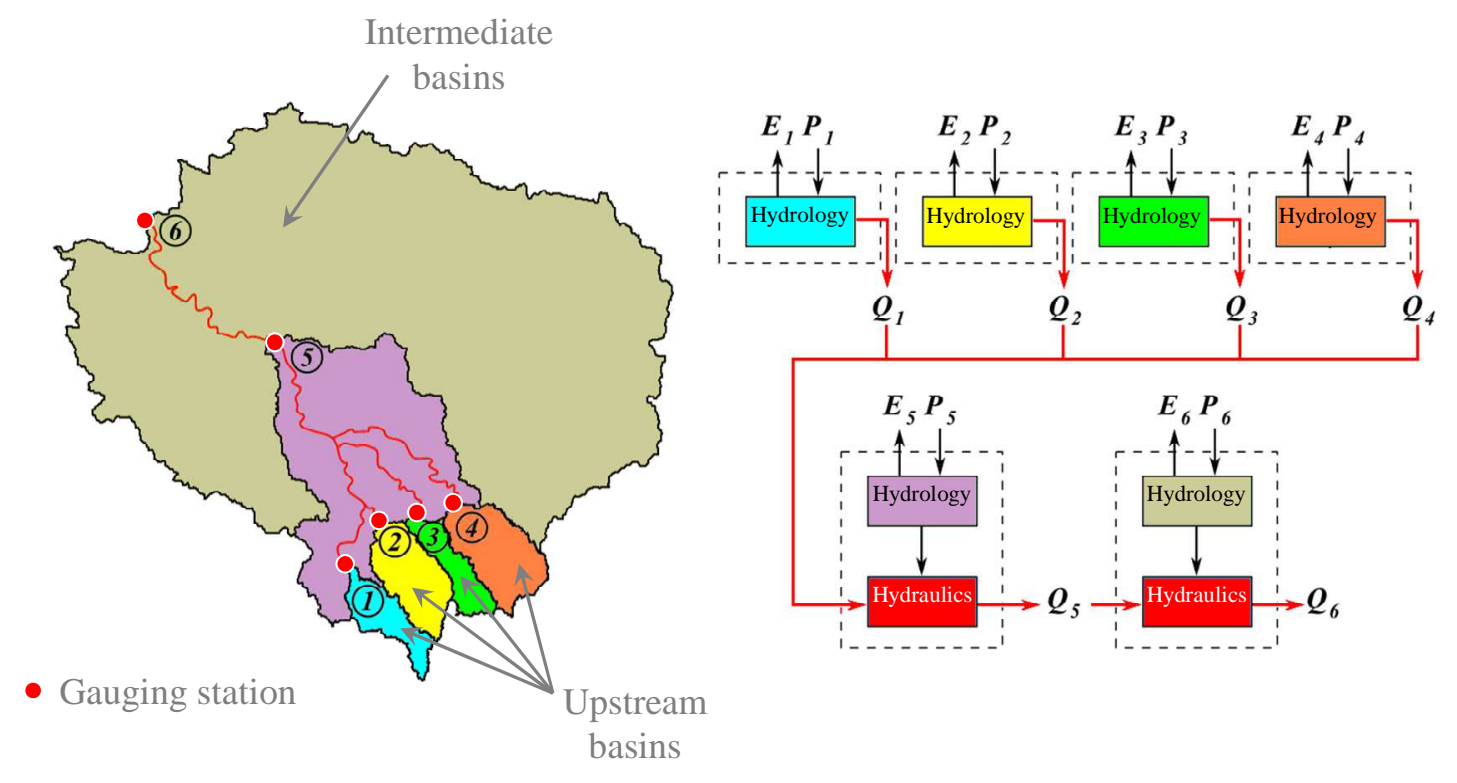

795 Figure 3: Schematic representation of the TGR model implementation for six gauging stations, coupling hydrological modelling of the upstream and intermediary basins and hydraulic routing (Adapted from Munier, 2009) 
Author-produced version of the article published in International Journal of River Basin Management JRBM, 2014, N¹2(3), p. 265-283. The original publication is available at http://www.tandfonline.com

Doi: $10.1080 / 15715124.2013 .865636$
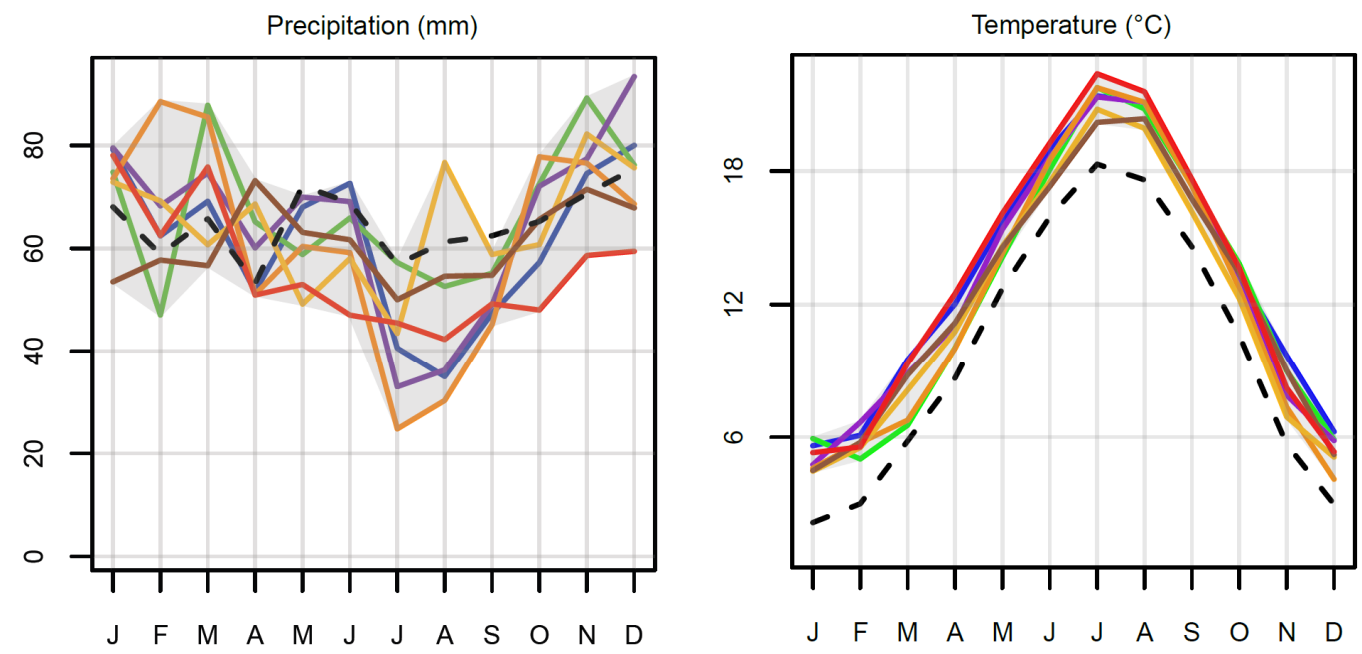

$\mathrm{PE}(\mathrm{mm})$

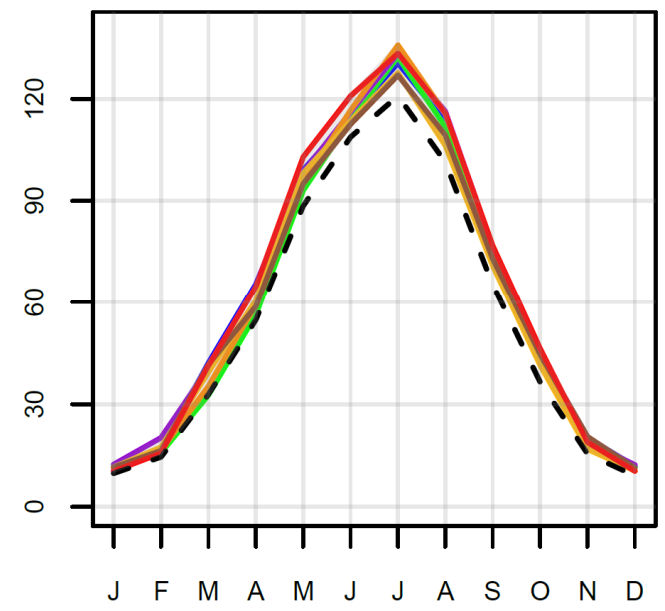

Figure 4: Monthly average of precipitation, temperature and potential evapotranspiration over the FUT period (2046-2065) for the Seine River basin at Paris. The dashed lines represent SAFRAN observations over the reference period and the coloured lines are the seven downscaled and bias-corrected climate simulations. 
Author-produced version of the article published in International Journal of River Basin Management JRBM, 2014, N¹2(3), p. 265-283. The original publication is available at http://www.tandfonline.com

Doi: $10.1080 / 15715124.2013 .865636$
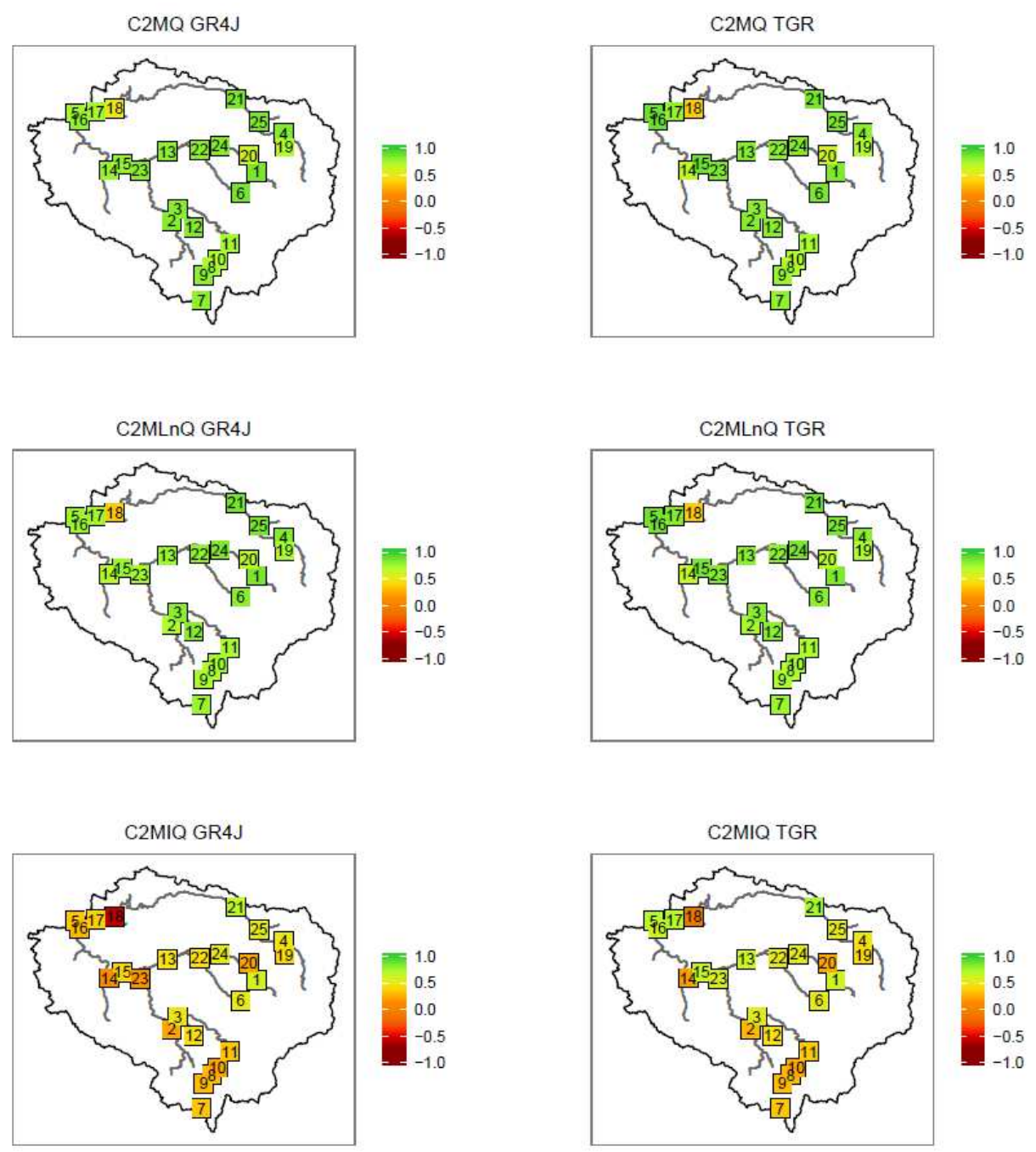

Figure 5: Efficiency criteria in validation (top: C2MQ; middle: C2MLnQ; bottom: CMIQ) obtained by the GR4J (left) and TGR (right) models in current conditions considering naturalized flows for the $\mathbf{2 5}$ gauging stations. 
Author-produced version of the article published in International Journal of River Basin Management JRBM, 2014, N¹2(3), p. 265-283. The original publication is available at http://www.tandfonline.com

Doi: 10.1080/15715124.2013.865636

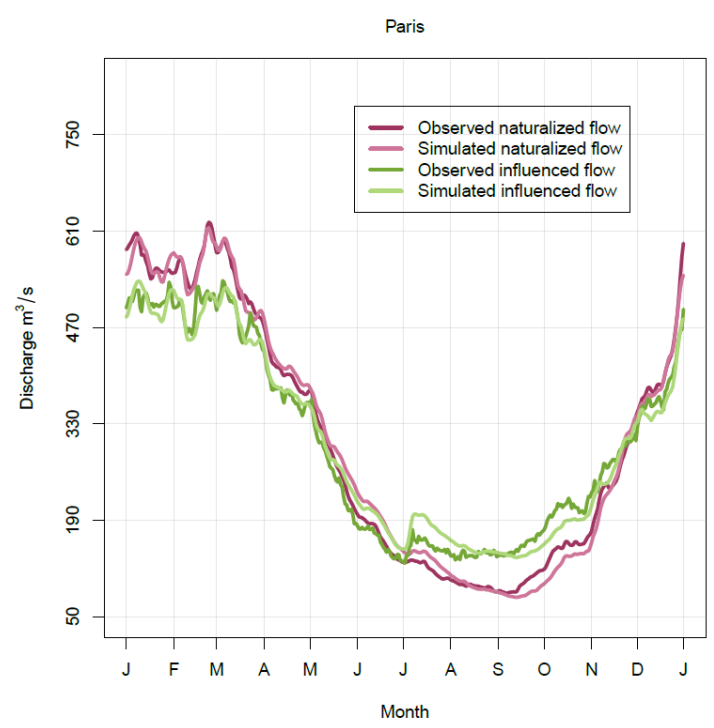

(a)

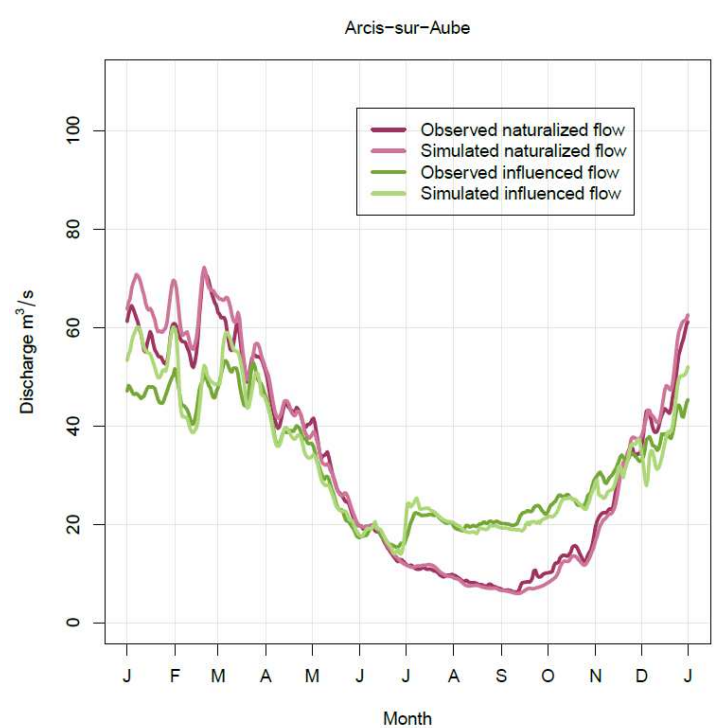

(b)

815 Figure 6: Mean daily flows for (a) the Seine River at Paris-Austerlitz and (b) the Aube River at Arcis-sur-Aube. Influenced and naturalized flows are shown for the 1991-2008 period. Simulations are produced by the TGR model in validation. 
Author-produced version of the article published in International Journal of River Basin Management JRBM, 2014, N¹2(3), p. 265-283. The original publication is available at http://www.tandfonline.com

Doi: 10.1080/15715124.2013.865636
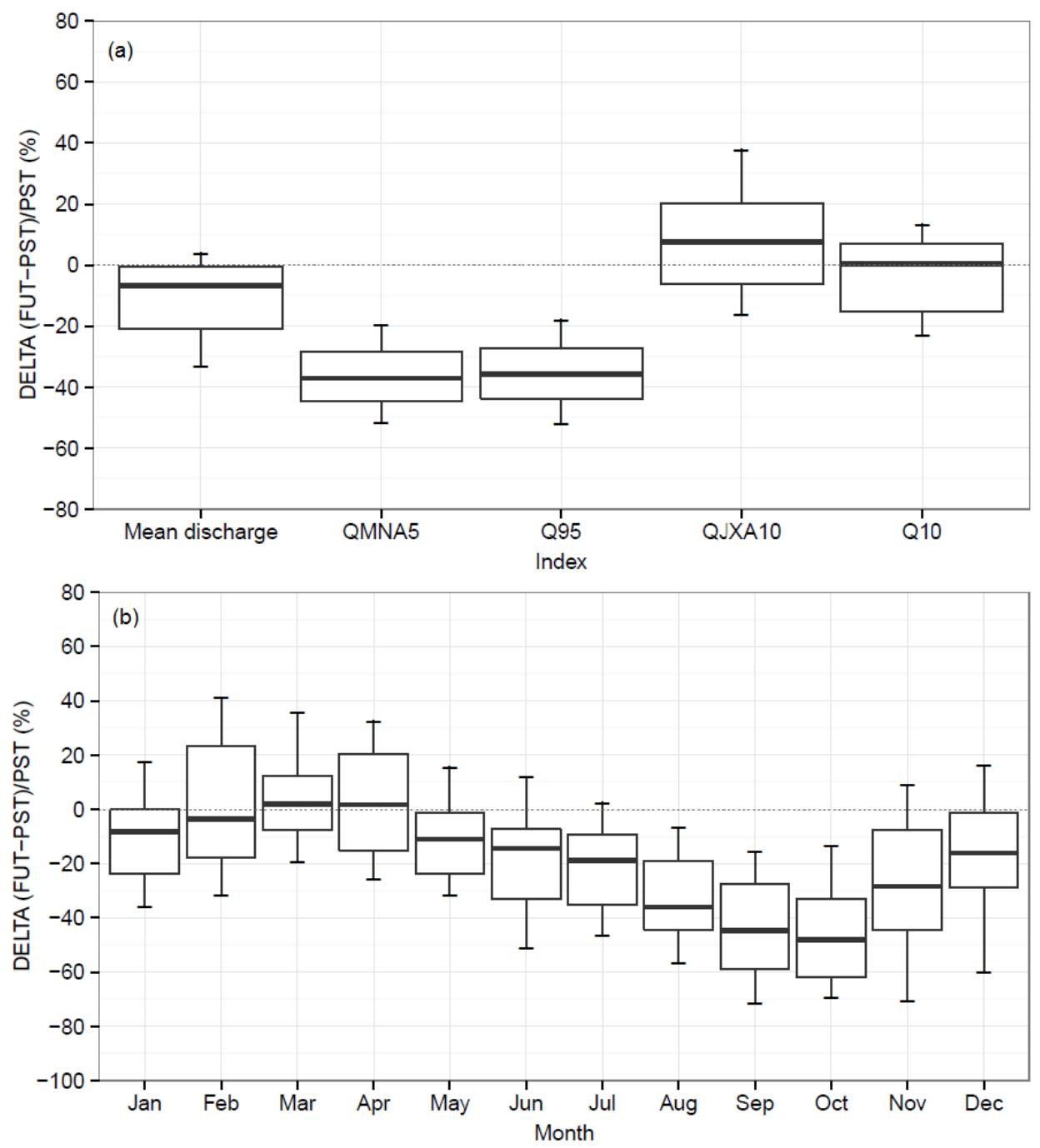

Figure 7: (a) Evolution $(\Delta)$ of the hydrological descriptors computed by the two hydrological models using the seven climate simulations on the 25 stations. The boxplots show the 5, 25, 50,75 , and $95 \%$ percentiles of the 14 simulations. (b) Evolution $(\Delta)$ of the monthly discharge for the 14 simulations 
Author-produced version of the article published in International Journal of River Basin Management JRBM, 2014, N¹2(3), p. 265-283. The original publication is available at http://www.tandfonline.com

Doi: $10.1080 / 15715124.2013 .865636$

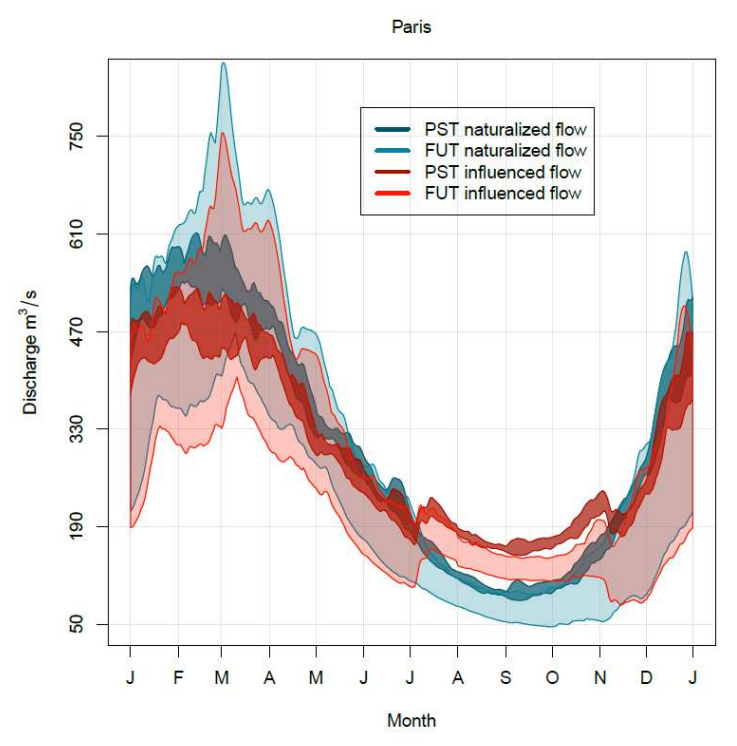

(a)

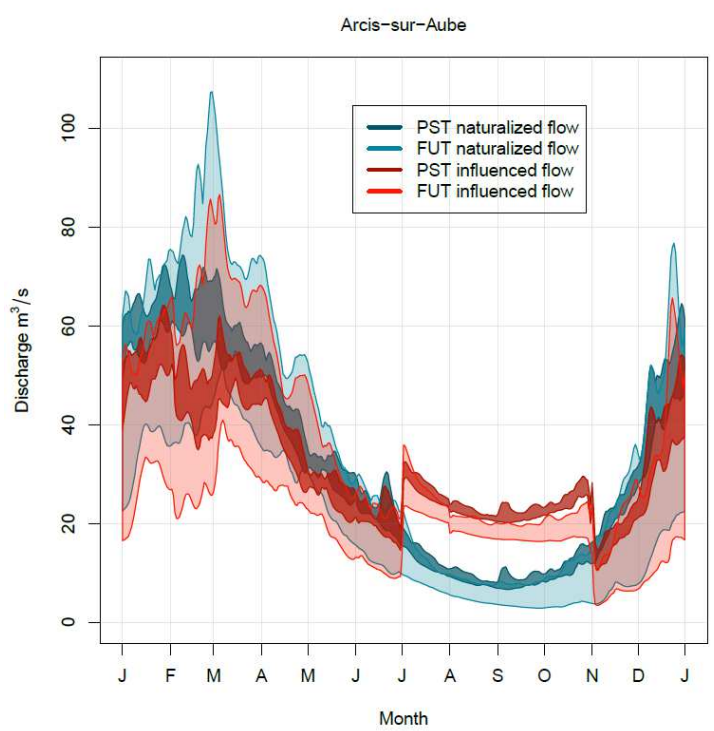

(b)

Figure 8: Evolution of daily mean discharge between present (PST) and future (FUT) conditions at (a) the Seine River at Paris-Austerlitz and (b) the Aube River at Arcis-sur-Aube. Discharge simulations are obtained using the TGR model run with the 7 climate simulations. The shaded colours represent the band widths of the 7 simulations. Discharge simulations are shown in natural and influenced conditions. 
Author-produced version of the article published in International Journal of River Basin Management JRBM, 2014, N¹2(3), p. 265-283. The original publication is available at http://www.tandfonline.com

Doi: 10.1080/15715124.2013.865636
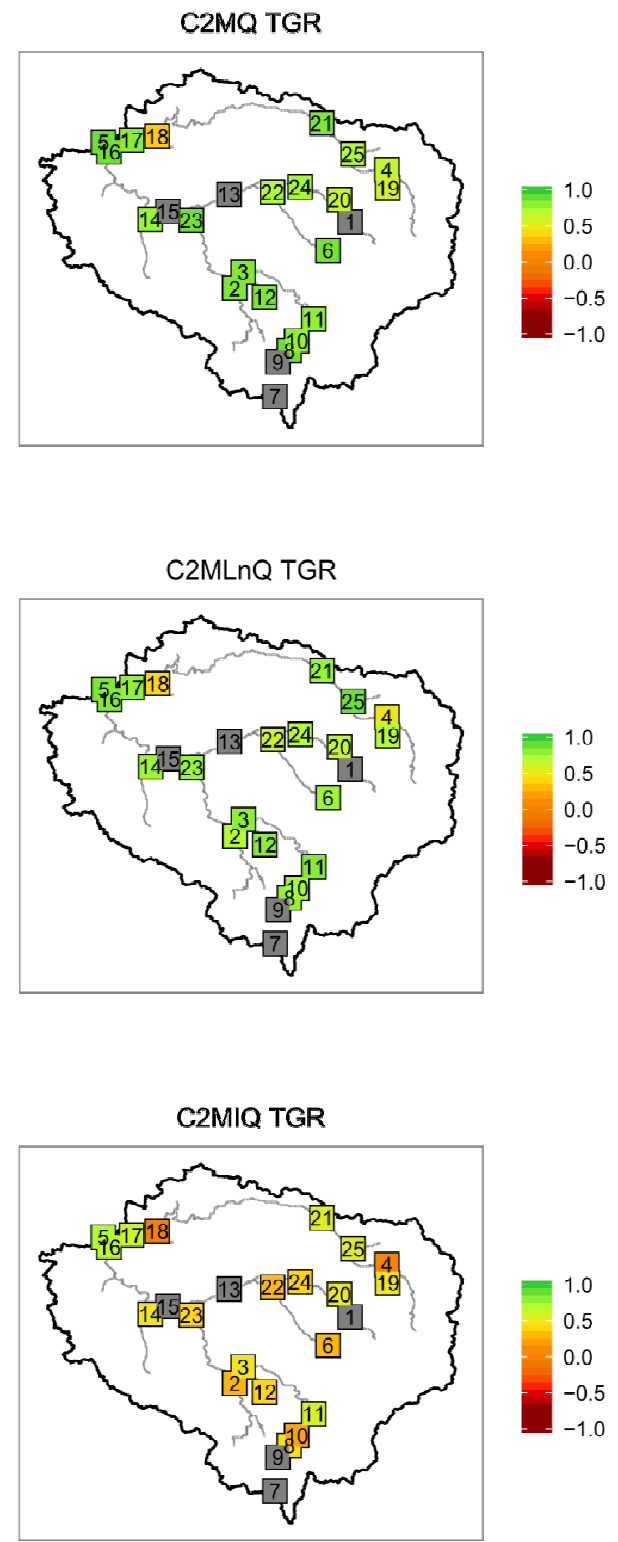

Figure 9: Efficiency criteria (top: C2MQ; middle: C2MLnQ; bottom: CMIQ) obtained by the integrated TGR model (accounting for reservoirs) in current conditions considering observed flows for the $\mathbf{2 5}$ gauging stations (in grey, stations where observed flows were not available). 
Author-produced version of the article published in International Journal of River Basin Management JRBM, 2014, N¹2(3), p. 265-283. The original publication is available at http://www.tandfonline.com

Doi: 10.1080/15715124.2013.865636
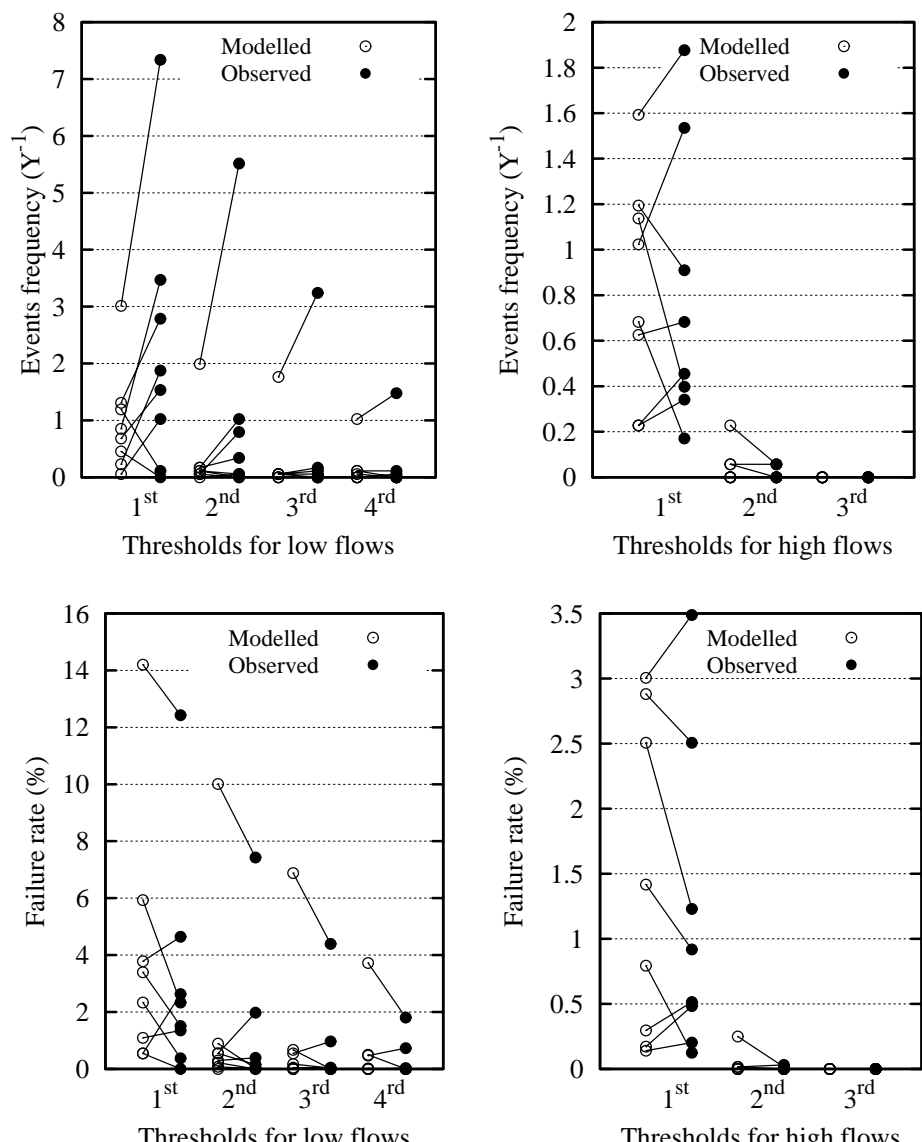

(a)

Thresholds for low flows
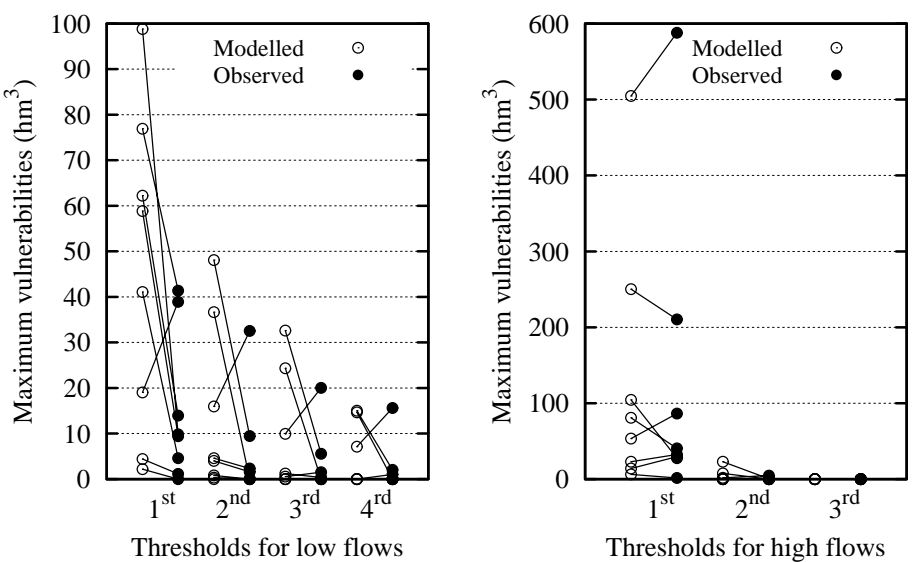

(b)

845 Figure 10: Efficiency criteria (a: event frequency; b: failure rate; c: maximum vulnerability) for the thresholds in low-flow (left) and high-flow (right) conditions using the observed (black dots) and simulated (white dots) flows under historical climate conditions (1991-2008) for all the monitoring stations 
Author-produced version of the article published in International Journal of River Basin Management JRBM, 2014, N¹2(3), p. 265-283. The original publication is available at http://www.tandfonline.com

Doi: 10.1080/15715124.2013.865636
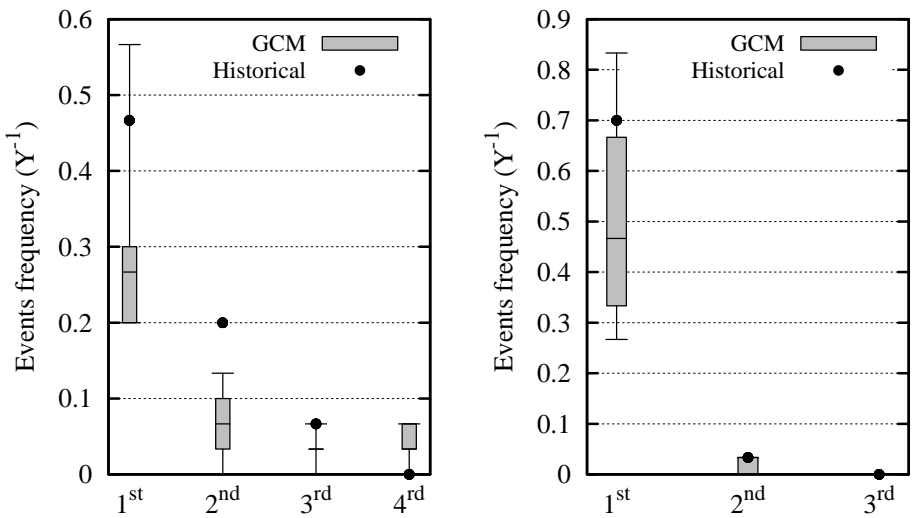

Thresholds for low flows at Paris

Thresholds for high flows at Paris

(a)
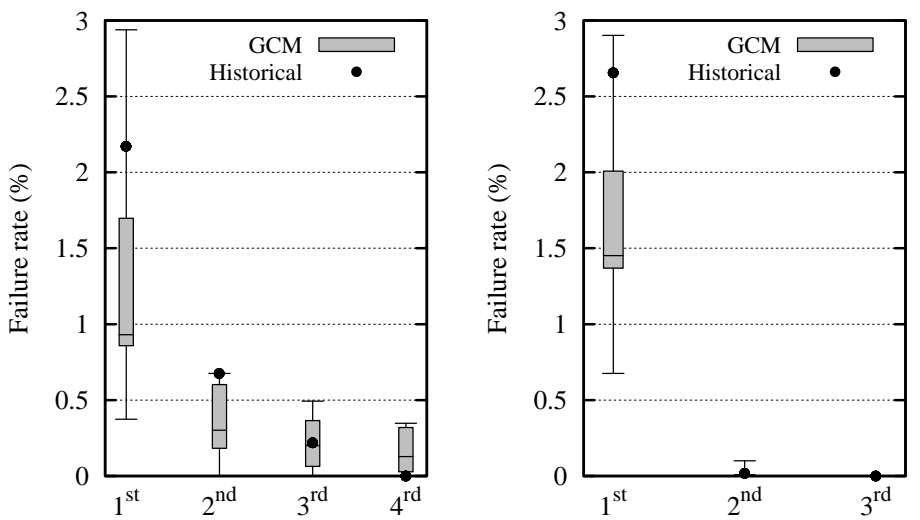

Thresholds for low flows at Paris

Thresholds for high flows at Paris

(b)
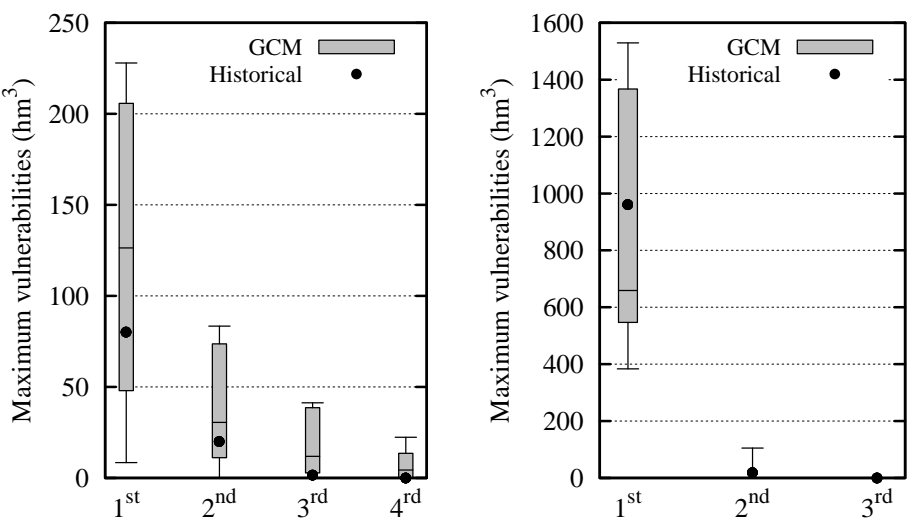

Thresholds for low flows at Paris

Thresholds for high flows at Paris (c)

Figure 11: Efficiency criteria (a: event frequency; b: failure rate; c: maximum vulnerability) for the thresholds in low-flow (left) and high-flow (right) conditions at Paris using the observed climate data (black dots) and the seven simulated climate data (grey bars) over the PST period (1961-1991) 
Author-produced version of the article published in International Journal of River Basin Management JRBM, 2014, N¹2(3), p. 265-283. The original publication is available at http://www.tandfonline.com Doi: $10.1080 / 15715124.2013 .865636$
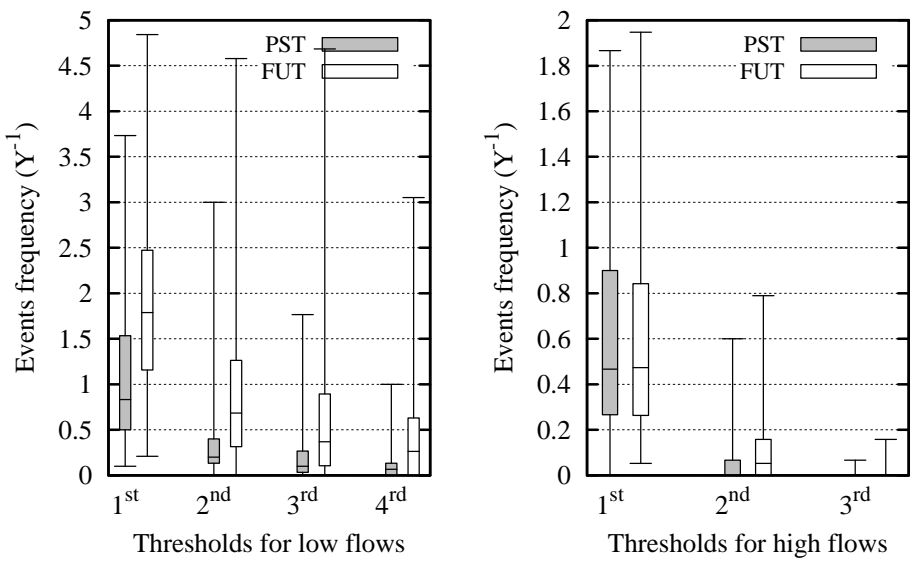

(a)
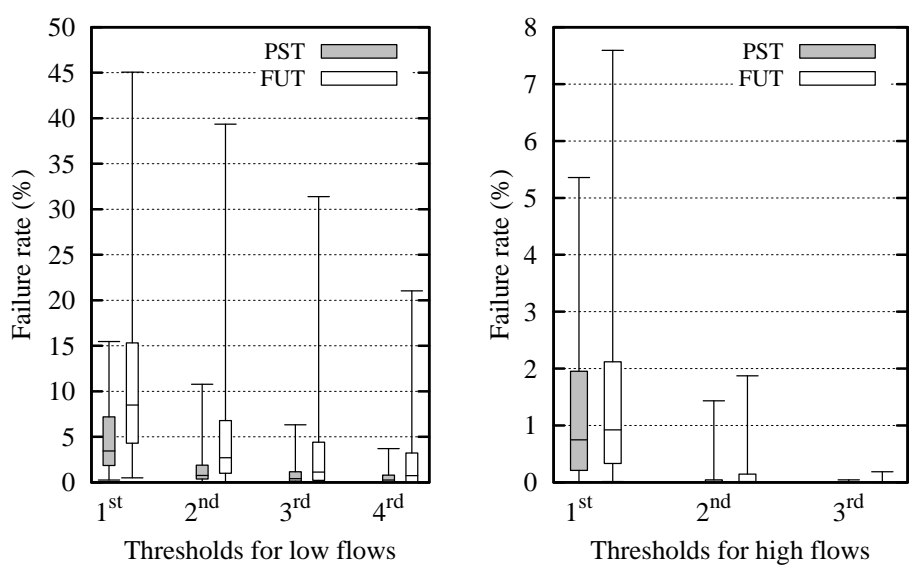

(b)
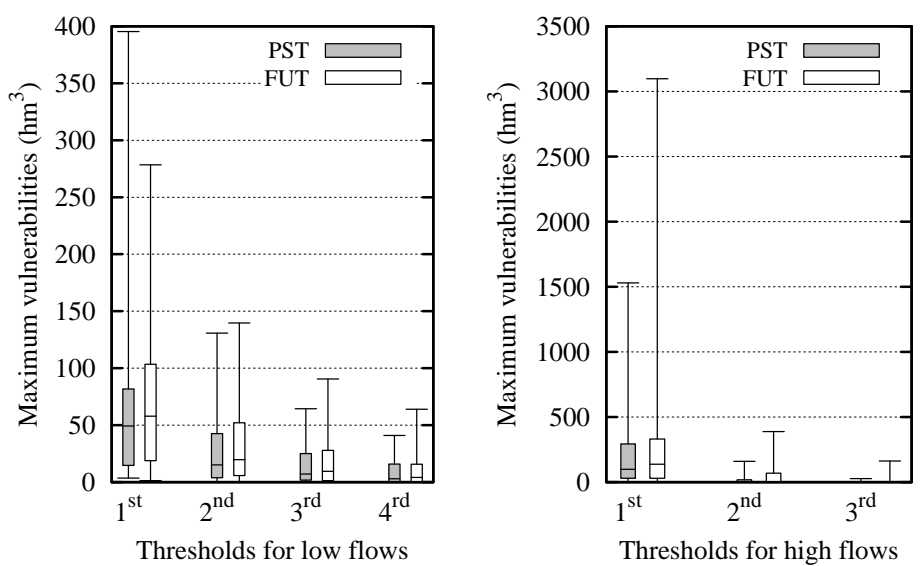

(c)

860 Figure 12: Efficiency criteria (a: event frequency; b: failure rate; c: maximum vulnerability) for the thresholds in low-flow (left) and high-flow (right) conditions under present and future conditions using the seven climate simulations for all monitoring stations 